Review

\title{
Deep Hypersaline Anoxic Basins as Untapped Reservoir of Polyextremophilic Prokaryotes of Biotechnological Interest
}

\author{
Stefano Varrella ${ }^{1}\left(\right.$, Michael Tangherlini ${ }^{2}\left(\mathbb{D}\right.$ and Cinzia Corinaldesi ${ }^{1, *}$ \\ 1 Department of Materials, Environmental Sciences and Urban Planning, Polytechnic University of Marche, \\ 60131 Ancona, Italy; s.varrella@univpm.it \\ 2 Stazione Zoologica Anton Dohrn, Villa Comunale, 80121 Napoli, Italy; michael.tangherlini@szn.it \\ * Correspondence: c.corinaldesi@univpm.it
}

Received: 28 November 2019; Accepted: 28 January 2020; Published: 30 January 2020

check for updates

\begin{abstract}
Deep-sea hypersaline anoxic basins (DHABs) are considered to be among the most extreme ecosystems on our planet, allowing only the life of polyextremophilic organisms. DHABs' prokaryotes exhibit extraordinary metabolic capabilities, representing a hot topic for microbiologists and biotechnologists. These are a source of enzymes and new secondary metabolites with valuable applications in different biotechnological fields. Here, we review the current knowledge on prokaryotic diversity in DHABs, highlighting the biotechnological applications of identified taxa and isolated species. The discovery of new species and molecules from these ecosystems is expanding our understanding of life limits and is expected to have a strong impact on biotechnological applications.
\end{abstract}

Keywords: marine prokaryotes; microbial diversity; polyextremophiles; deep hypersaline anoxic basins; blue biotechnologies; extremozymes; polyextremophiles; limits of life

\section{Introduction}

Deep-sea ecosystems (waters and seabeds of the ocean beneath $200 \mathrm{~m}$ depth) are the largest, most remote, and least explored biomes of the biosphere, comprising more than two-thirds of the oceanic volume [1-3]. They are characterized by absence of light, an average depth of approximately $4200 \mathrm{~m}$, temperatures below $4{ }^{\circ} \mathrm{C}$, and a hydrostatic pressure of about $40 \mathrm{MPa}$; taken together, these factors encompass some of the harshest environments on our planet, representing a challenge for the existence of life [2]. Over the last few decades, many deep-sea surveys have resulted in the discovery of highly diversified and peculiar habitats [2,4-6], including hydrothermal vents, cold seeps, mud volcanoes, and deep hypersaline anoxic basins, where life conditions are even more extreme [7]. Among these, deep hypersaline anoxic basins (DHABs) are defined as polyextreme ecosystems [8,9].

DHABs were discovered at the end of the last century on the seafloor in different deep-sea areas (at depths ranging from $630 \mathrm{~m}$ to $3580 \mathrm{~m}$ ) around the globe (Figure 1), including the Mediterranean Sea [10,11], the Red Sea [12-14] and the Gulf of Mexico [15]. Intriguingly, the discovery of new DHABs is still ongoing, such as with the recent discovery of the new Thetis, Kyros, and Haephestus basins in the Mediterranean Sea [16-18]. To date, with the recent finding of these new DHABs, 35 basins have been discovered around the world. The Bannock, Tyro, Urania, L'Atalante, and Discovery basins are the deepest known DHABs, being far below the photic zone (3200-3500 m deep), and are located along the Mediterranean Ridge in the Eastern Mediterranean Sea, an accretionary complex subjected to continental collision [19]. Two of the most studied DHABs in the Red Sea are the Shaban and the Kebrit deeps. The Shaban Deep comprises four depressions at a depth of $1325 \mathrm{~m}$, whereas the Kebrit Deep is a rounded basin of approximately $1 \mathrm{~km}$ in diameter found at a depth of $1549 \mathrm{~m}$ [20]. 


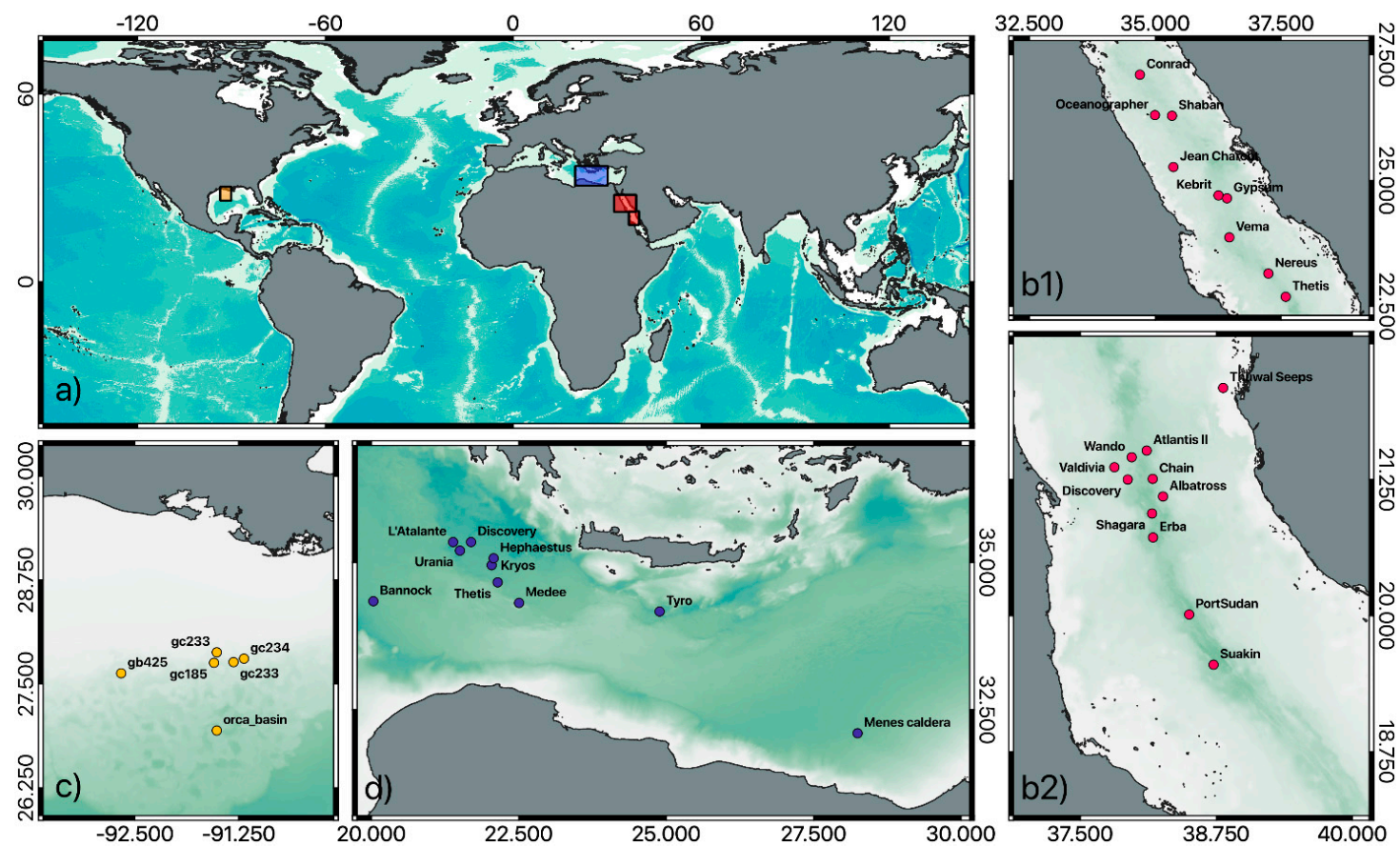

Figure 1. Global distribution of deep hypersaline anoxic basins (DHABs) (a). Locations and corresponding names of DHABs identified in the Red Sea (b1-b2), the Gulf of Mexico (c), and the Mediterranean Sea (d).

Different sampling strategies have been adopted to explore the general physical structure of DHABs. For instance, Mediterranean DHABs have been sampled through a rosette with Niskin bottles equipped with a conductivity, temperature, and depth (CTD) sensor and connected to a live camera to monitor the sampling operations [21-23]. Geochemical data of DHABs, such as those located in the Gulf of Mexico, have been collected through a brine-trapper, which was used to collect vertically water from different layers of the seawater-brine interface [24].

Despite the different geological features found in DHABs, most of them are derived from the re-dissolution of evaporitic minerals, like halite ( $\mathrm{NaCl}$-mineral) and kieserite $\left(\mathrm{MgSO}_{4}\right.$-mineral), after exposition to seawater due to tectonic activity $[25,26]$. This determines a salt-induced stratification of the water column (Figure 2), which drives the formation of a stable, dense, hypersaline brine lake with a variable thickness, ranging from one to tens of meters; this brine lake represents a polyextreme environment because its conditions hinder oxygen exchange, creating euxinic conditions, including high hydrostatic pressure, extremely low water activity and chaotropicity, and sharp oxy-, picno-, and chemoclines at the seawater-brine interface $[21,23,27]$. The salt concentration progressively increases over depth in the overlying halocline interface, reaching brines values up to 7-10 times higher than those existing in seawater [28]. 

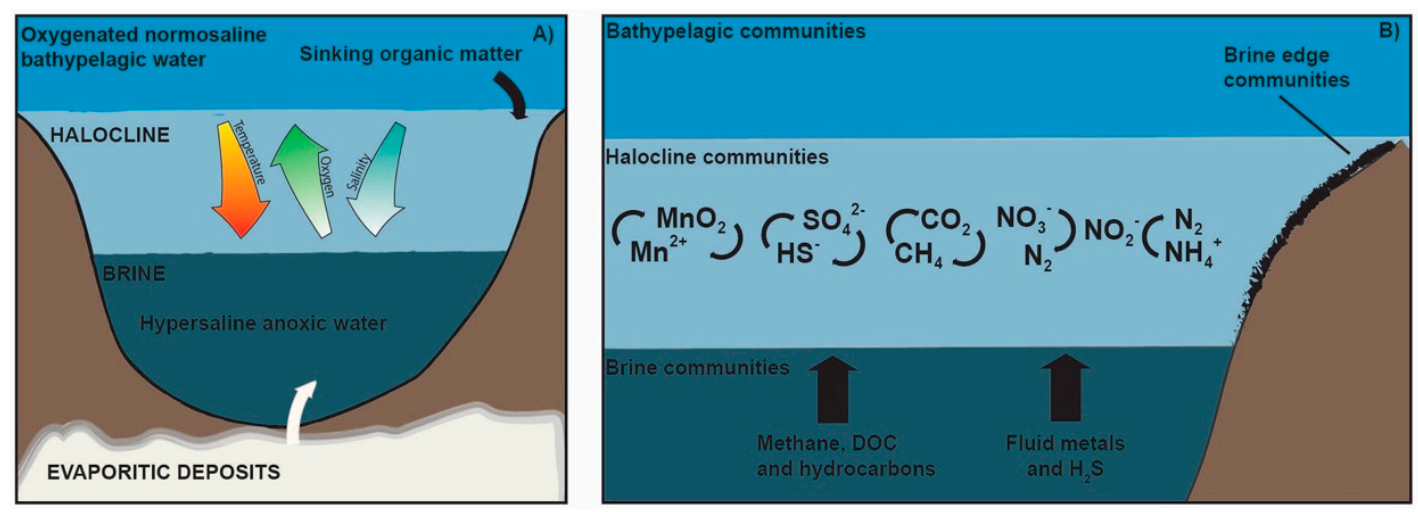

Figure 2. Simplified vertical section of a DHAB. The transition from the overlying seawater to the brine is commonly referred to as the halocline or brine-seawater interface, which is characterized by gradients of temperature, salinity, $\mathrm{pH}$, and dissolved oxygen (A); the main biogeochemical processes taking place within the halocline are shown in (B). From left to right, the manganese cycle, the sulfate reduction and sulfide oxidation cycle, the methanogenesis and aerobic (anaerobic) methane oxidation cycle, and the anammox and denitrification cycle that occur in the halocline are shown $[8,21,23,28-30]$. DOC: Dissolved Organic Carbon.

Chemical and physical characteristics are specific to each DHAB and greatly vary depending on how the brine was formed along with the geographic localization (Table 1). The majority of the DHABs are thalassohaline (most of the dissolved ions are represented by those composing the overlaying seawater), whereas the Discovery, Kryos, and Hephaestus basins are athalassohaline and are characterized by high $\mathrm{Mg}^{2+}$ concentrations likely deriving from the dissolution of magnesium chloride salts (i.e., bischofite [18])

Table 1. Minimum and maximum values of the main physicochemical variables observed among DHABs.

\begin{tabular}{lllll}
\hline Environmental Parameters & Ranges & DHABs & Location & References \\
\hline \multirow{2}{*}{ Temperature } & Min: $14^{\circ} \mathrm{C}$ & La Medee & Mediterranean Sea & {$[31]$} \\
& Max: $68^{\circ} \mathrm{C}$ & Atlantis II & Red Sea & {$[32]$} \\
Depth & Min $630 \mathrm{~m}$ & GC233 & Gulf of Mexico & {$[33]$} \\
& Max: $3580 \mathrm{~m}$ & Discovery & Mediterranean Sea & {$[17]$} \\
$\mathrm{Na}^{+}$ & Min: $1751 \mathrm{mM}$ & GC233 & Gulf of Mexico & {$[24]$} \\
& Max $5300 \mathrm{mM}$ & Tyro & Mediterranean Sea & {$[34]$} \\
$\mathrm{Cl}^{-}$ & Min: $2092 \mathrm{mM}$ & GC233 & Gulf of Mexico & {$[24]$} \\
& Max: $10,154.3 \mathrm{mM}$ & Discovery & Mediterranean Sea & {$[17]$} \\
$\mathrm{Mg}^{2+}$ & Min: $8.7 \mathrm{mM}$ & GB425 & Gulf of Mexico & {$[24]$} \\
& Max: $5143 \mathrm{mM}$ & Discovery & Mediterranean Sea & {$[17]$} \\
$\mathrm{K}^{+}$ & Min: $17.2 \mathrm{mM}$ & Orca & Gulf of Mexico & {$[35]$} \\
& Max: $471 \mathrm{mM}$ & La Medee & Mediterranean Sea & {$[31]$} \\
$\mathrm{Ca}^{2+}$ & Min: $1 \mathrm{mM}$ & Discovery, Kyros & Mediterranean Sea & {$[17]$} \\
& Max: $150 \mathrm{mM}$ & Atlantis II & Red Sea & {$[36]$} \\
$\mathrm{SO}_{4}{ }^{2-}$ & Min: $<1 \mathrm{mM}$ & GB425; GC233 & Gulf of Mexico & {$[24]$} \\
$\mathrm{Sulfide}^{*}$ & Max: $333.1 \mathrm{mM}$ & L'Atalante & Mediterranean Sea & {$[17]$} \\
& Min: $0.002 \mathrm{mM}$ & GC233 & Gulf of Mexico & {$[24]$} \\
& Max: $16 \mathrm{mM}$ & Urania & Mediterranean Sea & {$[16]$} \\
\hline
\end{tabular}

Overall, DHABs can be subdivided into four different systems: the seawater-brine interface, brines, the brine-sediment interface, and the sediments underlying the brines. Each of these features is characterized by specific conditions such as the steep halocline at the water-brine interface or the anoxic conditions of the sediments beneath the brines. In addition, the geochemical characteristics of each DHAB are mostly dependent on their geological evolution and origin. The high density of the brine prevents their mixing with the overlying oxygenated seawater, thus making the DHABs 
completely anoxic [16]. Their different hydrochemistry and physical separation for thousands of years has made these systems greatly interesting for scientists due to their potential similarity with extraterrestrial environments $[18,34,37]$. Despite their extreme conditions, many studies have provided evidence of a highly active prokaryotic community and of the presence of living metazoans, greatly extending our knowledge regarding the limits of organisms' adaptions to life [20,27,38-48]. These organisms require specific adaptations for withstanding numerous physicochemical stresses [49].

The complex structure and conditions of the DHABs, such as the presence of the steep haloand oxyclines, have been found to influence the distribution, structure, and richness of the microbial communities living in these environments [19]. Many studies have been focused on the halocline, which entraps nutrients, sinking organic materials, minerals, and microbial cells, and creates environmental gradients of great interest not only for identifying and isolating novel organisms but also for clarifying their metabolic strategies employed for adapting to extreme conditions [19]. The variable accumulation of metals and nutrients, especially in the halocline, supports the presence of different ecological niches exploited by highly diverse microorganisms with peculiar features [38]. However, to date, our knowledge of how these organisms are affected and contribute to the geochemical properties of the DHABs is still limited.

The presence of life in these extreme environments has raised important questions about the molecular mechanisms that extremophiles have developed to overcome harsh conditions. Many studies have highlighted several peculiar adaptive strategies of halophilic microorganisms for maintaining stability and functionality of all their cellular components under such conditions [50,51]. Hence, microorganisms inhabiting extreme saline habitats not only have been considered useful subjects for ecological and evolutionary studies [50] but also hold an outstanding ability to produce bioactive molecules and enzymes, which can also be exploited for industrial and biotechnological purposes as well as for human wellness [52,53]. Considering the promising biotechnological potential of bacteria and archaea from DHABs due to their capability to live under extreme conditions, the present review provides an outline of the prokaryotic biodiversity in DHABs, highlighting their potential in producing enzymes and bioactive molecules for industrial, pharmaceutical, and environmental applications.

\section{Prokaryotic Assemblages of DHABs}

The specific characteristics and geochemical conditions of each DHAB have driven the development of different and highly-stratified communities. Brines and the seawater-brine interfaces, indeed, represent the most widely-studied domains within DHABs from both a taxonomic and ecological/functional point of view [21,23]. The halocline is a microbial "hotspot", harboring dense microbial populations that appear to be more metabolically active than those of the adjacent layers, with the presence of unique bacterial lineages having been found [21,22,44,54,55]. Several microbial lineages have been identified within DHAB brines. In particular, many members of the new Mediterranean Sea Brine Lake lineages (MSBL1-6) have been found extensively across hypersaline basins [56] from the Mediterranean to the Red Sea (despite their name), and include Archaea (e.g., MBSL1, which are sugar-fermenting organisms capable of autotrophic growth [23,56,57] and other major divisions of bacteria (MSBL2-6 [21,38]). Interestingly, the bacterial MSBL2 lineage has shown high similarity to the SB1 division found in the Shaban Deep brine pool, located in the Red Sea, which represents a novel halophilic lineage within bacteria, with no close cultivated relatives observed so far [28,38]. Similarly to the MBSL lineages, bacteria belonging to candidate division KB1 have been identified for the first time within the Kebrit Deep basin (Red Sea [20]) and subsequently have also been found in other DHABs of the Red Sea [58], as well as in other basins (e.g., the halocline of Mediterranean Sea brine pools and pools from the Gulf of Mexico [17,21,22,31,59]). Bacteria from this division can import and/or produce glycine betaine in response to osmotic stress [59]. The KB1 glycine betaine transport systems seem to aid not only in maintaining osmotic balance but also have a role in methane production [59]. Delta- and Epsilonproteobacteria are also widely distributed across DHABs. 16S rRNA gene libraries from the Bannock, Hephaestus, and L'Atalante basins (Mediterranean Sea) have provided 
evidence of the presence of sulfate-reducing Deltaproteobacteria (in particular belonging to the ANME-1 clade, responsible for the anaerobic oxidation of methane [16]) and sulfur-oxidizing Gamma- and Epsilonproteobacteria [21,22]. In the GC233 basin within the Gulf of Mexico, combining geochemical data and molecular analyses, different Deltaproteobacteria sulfate-reducers (related to Desulfosarcinales, Desulfobacterium, Desulfobulbus, and Desulfocapsa) and sulfide-oxidizing Epsilonproteobacteria have been found, leading to the hypothesizing of the presence of a sulfur-cycling microbial community [15,60].

Archaea associated with the ammonia-oxidizing Thaumarchaeota Marine Group I have also been found across several DHABs worldwide [18,21,22]. In particular, they have appeared to be the most representative prokaryotic members in different Red Sea DHABs, though with different contributions: in the Atlantis II and Discovery, 99\% of archaeal operational taxonomic units (OTUs) were found to belong to the phylum Thaumarchaeota, whereas in the Erba basin the percentage was about 64\% [30]. Members of this phylum are capable of fixing $\mathrm{CO}_{2}$ and oxidizing methane, contributing to dark primary production [61]. Overall, the dominant thaumarchaeal lineage is closer to the genus Nitrosopumilus [62]. The adaptation of this genotype to the hostile brine-sediment interface environment can be possible not only by increasing intra-cellular salt concentrations [63] but also for the presence of "acidic tuned" membrane proteins which show optimal activity and stability at high salinity [64]. Furthermore, genomic analyses have revealed the presence of specific pathways for taking up a mixture of osmolytes and other genes encoding for the biosynthesis of ectoine/hydroxyectoine, which are not present in mesopelagic clades [30]. However, different DHAB geochemistry may shape other thaumarchaeal lineages. Genomic analyses have revealed a newly isolated methanogenic archeon from the sulfide-rich halocline of Kebrit, which holds adaptive traits (e.g., osmoprotection and oxidative stress response) for counteracting the harsh local conditions [65].

Apparently, as high salinity is one of the main features of DHABs, halophilic organisms have been found across all the basins, and most of the isolated halophilic strains also display interesting metabolic features. In particular, 33 halotolerant bacterial strains have been isolated from the halocline of the Urania, Bannock, Discovery, and L'Atalante basins [66]. For instance, Halanaeroarchaeum sulfurireducens M27-SA2 is a sulfur-reducing and acetate-oxidizing haloarcheon isolated from the Medee basin [67]. Moreover, several novel strains have been isolated from Red Sea DHABs, such as Halorhabdus tiamatea (a non-pigmented, fermenting member of the Halobacteriaceae [68]) and Haloplasma contractile (a highly unusual contractile bacterium belonging to the Haloplasmatales order, which can grow under 0.2-3.1 M $\mathrm{NaCl}$ conditions [69]. Two other strains of a novel species, Marinobacter salsuginis SD-14BT and SD-14C, have also been isolated from the halocline of the Shaban Deep [70].

In general, prokaryotic diversity and activity appear to be less marked in sediments under brines than in deep-sea control sediments [55]. This is likely due to the cumulative physico-chemical stressors that greatly limit the survival of microorganisms which could be better adapted to the extreme DHAB chemocline [27,55,71]. Proteobacteria, Actinobacteria, Deferribacteres, and Euryarchaeota have been found in sediments underlying either Discovery Deep or Atlantis II [72]. In the sediments of L'Atalante, OTUs belonging to the Pseudoalteromonas, Halomonas, and Pseudomonas genera have been observed to be the most represented within the abundant Gammaproteobacteria class, suggesting a mixed assemblage of halophilic and halotolerant microorganisms [55]. In addition, metatranscriptomic analyses have revealed that, in the sediments underlying the Urania basin, most transcripts are affiliated with rRNAs of the genera Pseudomonas, Rhodobacter, and Clostridium, and with sequences associated with mitomycin antibiotics typically produced by Streptomyces [71]. Prokaryotes inhabiting DHAB sediments are killed by viruses, which may represent the main mechanism of top-down control of prokaryotic dynamics in these ecosystems [42]. Since viruses are found to be well-preserved in DHAB sediments, they can shape prokaryotic assemblages [41]. Based on this information, it is possible to hypothesize that prokaryotes of DHABs can produce specific molecules against viral infections. 


\section{Biotechnological Potential of Prokaryotes Inhabiting DHABs}

Generally, marine microorganisms represent an untapped source for the discovery and development of new biomolecules due to their rich biodiversity and genetic capacity to produce unique metabolites [73-75]. In this regard, it is well documented that many taxonomically novel marine species are promising sources of new bioactive compounds with noteworthy pharmaceutical activities, which can become sources of novel therapeutic agents [52,76]. In particular, marine extreme environments, like deep-sea and polar ecosystems or DHABs, have been revealed to be a rich source of secondary metabolites with novel structures and outstanding biological activities [28,52,77].

Due to the limited accessibility and remoteness of such extreme ecosystems and the need for sophisticated instruments for exploring and investigating them, they are still largely understudied and underexploited in comparison with terrestrial ecosystems.

Over the last few years, the advancement of technologies for deep-sea exploration [78] and "-omics" (e.g., environmental shotgun sequencing and metatranscriptomics) for the analysis of environmental strains of prokaryotes has revolutionized bioprospecting in extreme environments, thus increasing our knowledge of the genetic potential of microbial communities for the discovery of enzymes with a commercial value $[79,80]$. In addition, functional screening of extremophile metagenomes could represent a valuable approach to identify novel antibacterial and anticancer agents. In this regard, bioinformatic tools like the metabolite analysis shell (antiSMASH) have recently been used to detect from metagenomic samples collected from the Atlantis II, Discovery, and Kebrit DHABs promising specialized metabolism gene clusters (SMGCs) coding for products with reported antibacterial and anticancer effects, namely terpenes, peptides, polyketides, and phosphonates [81]. Two clones belonging to these libraries which exhibited antibacterial effects were screened by high-throughput sequencing (NGS) and bioinformatic analyses along with cytotoxicity assay (MTT) testing of the whole cell lysates against different cancer cell lines (MCF-7, U2OS, and 1BR-hTERT) [82]. Although culture-independent approaches have radically changed microbial bioprospecting in extreme environments, the development of biotechnological applications must be accompanied by the corresponding study of pure cultures. In this regard, despite the great biodiversity-highlighted trough metagenomics in DHABs, so far less than 100 bacterial strains (Figure 3, Table S1) have been isolated and cultured for testing their extracts in few biotechnological applications [66,83-85]. Bioinformatic analyses on the phylogeny of the 16s rDNA sequences of those cultured strains (carried out by aligning them on the SILVA database v132 on the ACT server [86]) showed that most of these prokaryotes are affiliated with Gammaproteobacteria and Bacilli; in addition, several sequences within the same database were found to be phylogenetically related to the cultured strains (Table S2), further suggesting that more prokaryotic strains with adaptations to polyextreme ecosystems with biotechnological potential might be found within the same clades of already-cultured strains. Novel sampling and cultivation methods should be developed as alternatives to overcome culture limitations, especially in extreme environments [87].

Since the beginning of the new millennium, a number of studies have indicated the beneficial roles of extremophilic marine prokaryotes, which are a relevant but still underexplored source of bioactive molecules of commercial significance [74,88,89]. Extremophiles undoubtedly show unique capabilities and adaptations which allow them to thrive in systems characterized by harsh environmental conditions [90]. In fact, polyextremophilic microorganisms utilize alternative metabolic pathways and adaptive mechanisms which have important applications in industrial and environmental fields [50]. Since these microorganisms live in a biologically competitive environment for space and nutrients, they have developed mechanisms of defence against competitors and predators for their own survival, synthesising secondary metabolites of great value in pharmaceutical and biotechnological applications [91,92]. The advances in genome sequencing of extremophilic microorganisms have allowed us to provide a comprehensive understanding of their applications [93-95]. Moreover, microbes with large genomes, usually inhabiting complex harsh environments, can produce a vast array of secondary metabolites [96,97]. 


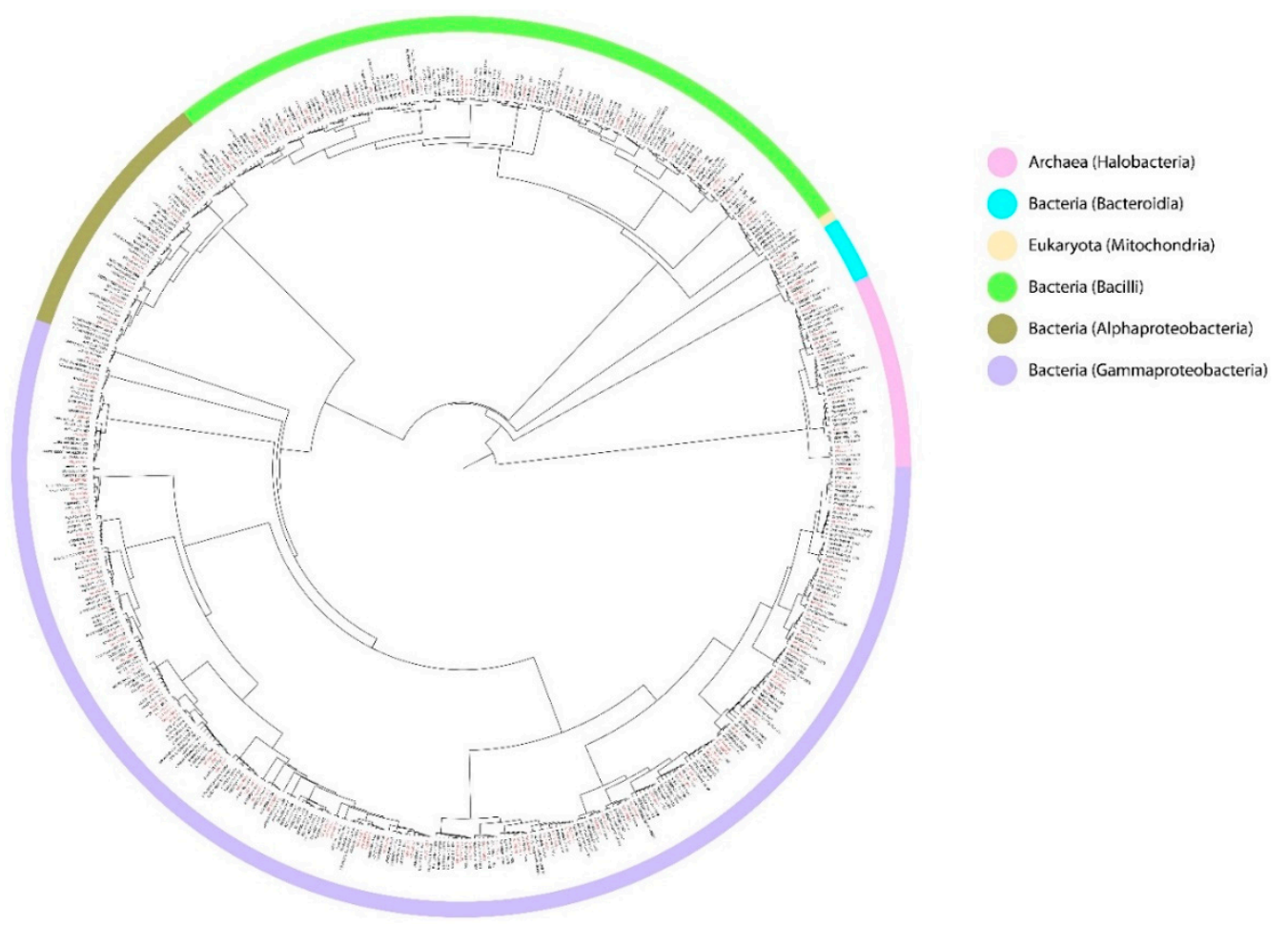

Figure 3. Phylogenetic tree of bacterial and archaeal strains isolated from DHABs. The tree was built using $16 \mathrm{~S}$ rRNA gene sequences from [66,83-85] and phylogenetically close 16s rRNA sequences from the SILVA database v132.

\subsection{DHABs as a Hidden Treasure for Biodiscovery of Pharmaceuticals}

Over the last 50 years, the development of new multidrug-resistant pathogens, along with the consequent increase in infectious diseases, has become an important issue for human wellness [98]. Furthermore, anticancer chemotherapeutic resistance is recently becoming a biomedical challenge, arising either intrinsically or extrinsically, after therapy [99]. Thus, the need for the discovery and development of novel antimicrobial and chemotherapeutic drugs with new modes of action is nowadays becoming of fundamental importance $[100,101]$. Since most of the antibiotics currently available on the market have been extracted from terrestrial organisms or derived semisynthetically from fermentation products, the isolation of microorganisms from marine habitats represent an interesting possibility which can lead to the discovery of novel structures with antibiotic activity [102,103].

As such, the prokaryotic genera identified in DHABs isolated from different marine environmental sources, including extreme environments, represent an authentic treasure of many bioactive compounds useful for biomedical applications (Table 2). 
Table 2. Bioactive molecules for pharmaceutical use produced by prokaryotes directly isolated from DHABs and promising bioactive molecules produced by prokaryotic taxa which have been identified in DHABs and isolated from other marine systems.

\begin{tabular}{|c|c|c|c|c|}
\hline Marine Prokaryotes & Product & Bioactivity & Environmental Sources & Ref. \\
\hline Alteromonas macleodii & Dithiolopyrrolone & Antibiotic and antitumor & Erba and Nereus DHABs & {$[84,104]$} \\
\hline Alteromonas sp. B-10-31 & Marinostatins B-1, C1, and C2 & Serine protease inhibitor & Coastal seawater & [105] \\
\hline Bacillus sp. & Macrolactins A-F & $\begin{array}{l}\text { Cytotoxic, antimicrobial, } \\
\text { antiviral }\end{array}$ & Deep sea & [106-109] \\
\hline Bacillus halodurans & Enfuvirtide & Antiviral & Nereus DHAB & {$[84,110]$} \\
\hline Bacillus MK-PNG-276A & Loloatins A-D & Antimicrobial & Great barrier reef & [111] \\
\hline Bacillus sp. & Bogorol A & Antimicrobial & Seawater & [112] \\
\hline Bacillus sp. CND-914 & Halobacillin & Antitumor & Deep-sea sediments & [113] \\
\hline Bacillus sp. MIX-62 & Mixirins A-C & Antitumor & & [114] \\
\hline Bacteroidetes rapidithrix $\mathrm{HC} 35$ & Ariakemicins A and B & Antimicrobial, cytotoxic & Sea mud & [115] \\
\hline Erythrobacter sp. & $\begin{array}{l}\text { Erythrazoles A and B } \\
\text { Erythrolic acids A-E }\end{array}$ & Cytotoxic & Mangrove sediments & {$[116,117]$} \\
\hline Halobacteroides lacunaris TB21 & R-LPS & Immunomodulator & Thetis DHAB & [118] \\
\hline Halomonas LOB-5 & Loihichelins A-F & n.a. & Deep sea hydrothermal vents & [119] \\
\hline Halomonas meridiana & n.a. & Antitumor & Nereus DHAB & [84] \\
\hline Halomonas sp. GWS-BW-H8hM & $\begin{array}{l}\text { 3-(4'-Hydroxyphenyl)-4-phenylpyrrole- } \\
\text { 2,5-dicarboxylic acid (HPPD-1 and HPPD-2) } \\
\text { 2-Amino-6-hydroxyphenoxazin-3-one2- }\end{array}$ & Cytotoxic & Seawater & {$[120]$} \\
\hline Halomonas sp. GWS-BW-H8hM & $\begin{array}{l}\text { Amino-8-benzoyl-phenoxazin-3-one2-Amino-8- } \\
\text { (4-hydroxybenzoyl)-6-hydroxyphenoxazin-3-one }\end{array}$ & Antimicrobial, cytotoxic & Seawater & [121] \\
\hline Pseudoalteromonas carrageenovora IAM 12662 & LPS & Antiviral & Erba DHAB & {$[84,122]$} \\
\hline Pseudoalteromonas haloplanktis TAC125 & Peptides & Antioxidant & Antarctic coastal sea water & [123] \\
\hline Pseudoalteromonas mariniglutinosa & n.a. & Antitumor & Erba and Nereus DHABs & [84] \\
\hline Pseudoalteromonas rava SANK 73390 & Thiomarinols A-H and J & Antimicrobial & Seawater & {$[124,125]$} \\
\hline Streptomyces aureoverticillatus (NPS001583) & Aureoverticillactam & Antitumor & Marine sediments & [126] \\
\hline Streptomyces C42 & Champacyclin & Antimicrobial & Deep sea & [127] \\
\hline Streptomyces CNH-990 & Marmycins $\mathrm{A}$ and $\mathrm{B}$ & Cytotoxic & Seawater & {$[128,129]$} \\
\hline Streptomyces drozdowiczii SCSIO 10141 & Marfomycins A, B, and E & Anti-infective & Deep sea & [130] \\
\hline Streptomyces drozdowiczii NTK 97 & Frigocyclinone & Antimicrobial & Antarctica & {$[131]$} \\
\hline Streptomyces Merv 8102 & Essramycin & Antimicrobial & $\begin{array}{l}\text { Marine animals, plants, and } \\
\text { sediments }\end{array}$ & [132] \\
\hline Streptomyces niveus SCSIO 3406 & Marfuraquinocins & Cytotoxic antimicrobial & Deep sea & [133] \\
\hline Streptomyces scopuliridis SCSIO ZJ46 & Desotamide B & Antimicrobial & Deep-sea sediments & [134] \\
\hline Streptomyces sioyaensis SA-1758 & Altemicidin & Cytotoxic, antimicrobial & Sea mud & {$[135]$} \\
\hline Streptomyces sp. 12A35 & Lobophorins $\mathrm{H}$ and I & Antimicrobial & Deep sea & [136] \\
\hline
\end{tabular}


Table 2. Cont.

\begin{tabular}{|c|c|c|c|c|}
\hline Marine Prokaryotes & Product & Bioactivity & Environmental Sources & Ref. \\
\hline Streptomyces sp. ART5 & Articoside & \multirow{3}{*}{$\begin{array}{l}\text { Cytotoxic, } \\
\text { anti-inflammatory } \\
\text { Antimicrobial, cytotoxic, } \\
\text { anti-apoptotic }\end{array}$} & Arctic deep sea & [137] \\
\hline Streptomyces sp. CNB-982 & Cyclomarins A-C & & Marine sediments & {$[138,139]$} \\
\hline Streptomyces sp. CNQ-418 & Marinopyrroles A-F & & Deep-sea sediments & {$[140,141]$} \\
\hline Streptomyces sp. CNQ-85 & $\begin{array}{l}\text { Daryamides A-C } \\
(2 \mathrm{E}, 4 \mathrm{E})-7-\text {-Methylocta-2,4-dienoic acid amide } 26\end{array}$ & Antitumor, antifungal & Seawater & [142] \\
\hline Streptomyces sp. CNR-698 & Ammosamides A-D & Cytotoxic & Deep sea & [143-145] \\
\hline Streptomyces sp. M045 & Chinikomycins A and B & Antitumor & Seawater & [146] \\
\hline Streptomyces sp. MDF-04-17-069 & Tartrolon D & Cytotoxic & Marine sediments & {$[147]$} \\
\hline Streptomyces sp. Mei37 & Mansouramycins A-D & Antimicrobial, cytotoxic & Marine sediments & {$[148]$} \\
\hline Streptomyces sp. NTK 935 & Benzoxacystol & Antiproliferative & Deep sea & [149] \\
\hline Streptomyces sp. SCSIO 03032 & Spiroindimicins A-D & Antitumor & Deep sea & {$[150]$} \\
\hline Streptomyces sp. SCSIO 11594 & Dehydroxyaquayamycin, Marangucycline B & Antibacterial, antitumor & Deep sea & {$[151]$} \\
\hline Streptomyces xiamenensis M1-94P & Xiamenmycin C and D & Anti-fibrotic & Deep-sea sediments & [152] \\
\hline Streptomycete sp. & Piperazimycins A-C & Antitumor & Marine sediments & [153] \\
\hline Zunongwangia profunda SM-A87 & EPS & Antioxidant & Nereus DHAB & [154] \\
\hline
\end{tabular}


For instance, in Mediterranean DHABs transcripts related to Streptomyces have been identified, thus representing an important source of bioactive natural products with clinical or pharmaceutical applications [71,155]. Additionally, Pseudoalteromonas flavipulchra recently isolated from the Nereus halocline shows great antimicrobial activity which is associated with the different metabolites and/or enzymes that this species can produce $[84,156,157]$.

An attractive example of the potential of extremophiles in the biomedical field has been provided by Halobacteroides lacunaris TB21, which was isolated from Thetis basin [118]. This polyextremophile organism produce a lipopolysaccharide (LPS) analog which can bind to the TLR4/MD-2 complex in HEK 293 hTLR4 cells, exerting an immunostimulant activity [118]. Additionally, Pseudoalteromonas carrageenovora isolated from Erba basin sediments is able to produce an LPS whose function is still undescribed [84,122]. This halophilic bacterium can also produce low molecular weight products from carrageenans, which have been reported to hold protective effects against the human immunodeficiency virus, the yellow fever virus, the herpes simplex viruses, the vaccine virus, and the pig fever virus [158]. Another interesting species isolated from the Nereus brine-pool-sea-water interface is Bacillus halodurans, which was engineered for the production of the anti-viral therapeutic peptide Enfuvirtide, marketed by Roche under the trademark Fuzeon ${ }^{\circledR}$, which has given rise to possibilities for pharmaceutical applications [84,110]. In addition, Zunongwangia profunda, inhabiting the same interface, produces exopolysaccharides (EPS) with antioxidant properties [154].

Innovative research was carried out for screening the bioactivity of molecules extracted from the Atlantis II, Discovery, Kebrit, Nereus, and Erba DHABs [83,85]. Extracts from 36 isolates were tested on three different human cancer cell lines: HeLa, MCF-7, and DU145 [83,85]. In particular, many extracts from Halomonas strains have been found to induce apoptotic and cytotoxic effects. For example, Halomonas meridiana collected from Nereus halocline has been observed to prompt apoptosis of MCF-7 cells [85]. Recently, it was shown that the extract of Pseudoalteromonas mariniglutinosa collected from Erba and Nereus haloclines also inhibited the growth of MCF-7 cells [84]. Halomonas species can produce EPS which have been shown to have pro-apoptotic activity towards human T-leukemia cells and breast cancer MCF-7 cells [159,160]. Other bioactive extracts derived from Chromohalobacter salexigens, Chromohalobacter israelensis, Halomonas meridiana, and Idiomarina loihiensis have been found to be able to induce more than $70 \%$ mortality in HeLa cancer cells through different caspase-mediated apoptotic pathways [83].

Intriguingly, three extracts belonging to the genus Salinivibrio have been found to specifically blocked the growth of fibrosarcoma cells (HT-1080), opening up interesting perspectives for the discovery of new bioactive compounds produced by this genus [84]. The extracts of Halomonas hamiltonii and Alcanivorax dieselolei have been observed to inhibit the proliferation of BT20 cells, whereas the Alteromonas macleodii extracts collected from Nereus and Erba halocline were found to inhibit the cell growth of HCT [84]. Alteromonas species are also well known for producing dithiolopyrrolone, a potent antibiotic approved by the Food and Drug Administration and commercialized as Bactroban ${ }^{\circledR}$ (GlaxoSmithKline) [104]. These studies emphasize the wide diversity of brine pool microorganisms capable of producing bioactive molecules, highlighting the incredible potential of DHABs as a source of novel molecules exploitable in the pharmacological industry.

\subsection{DHABs as a Reservoir of Polyextreme Enzymes}

Today's society is moving toward "white" (i.e., industrial) biotechnology, which is growing for its efficiency from environmental and commercial points of view [161]. For example, natural enzyme catalysis has been utilized for application in a broader range of industrial settings, representing a valuable alternative to its chemical catalysts [162-164]. It is expected that $40 \%$ of the industrial application of chemical reactions that require organic solvents harmful to the environment will be replaced by enzymatic catalysis by 2030 [165]. The continuous demand for natural new enzymes that are biocompatible and non-toxic and which have high activity over a wide range of conditions, including temperature, salinity, $\mathrm{pH}$, and metal concentrations, has been scaled up within pharmaceutical, 
food, and beverage industrial processes [166]. Hence, extremophilic microorganisms represent important sources of stable and valuable enzymes which are used as biocatalysts in industrial and biotechnological processes [53]. Enzymes from these organisms, which are called "extremozymes" due to their special features, can catalyze chemical reactions under conditions which inhibit or denature the non-extreme forms [167], including high salinity, acidic or basic $\mathrm{pH}$, and high temperatures [168]. Thus, through the use of genetic engineering and/or by bioprospecting of extreme environments it is possible to discover and develop new extremozymes that can be suitable for many industrial processes [164]. Extremophilic bacteria and archaea produce enzymes which can be employed in industrial reactions using either directly living organisms or purified molecules, expanding the ranges of optimal enzyme performance and thus enabling biocatalysis under the enzymatically unfavourable conditions found in industrial processes [169]. Hence, the peculiar characteristics of extremophiles belonging to prokaryotic domains living in DHABs can represent a new source for exploitable enzymes for their capacity to operate under extreme conditions [170,171]. In fact, many of these molecules (e.g., aldehyde dehydrogenase, proteases, cellulases, esterases, ferredoxin oxidoreductase, agarase, amylases, $\mathrm{k}$-Carragenases, ketoreductases, and cyclodextrin glycosyltransferase) have been commercialized and have applications in different biotechnological areas with considerable benefits for many kinds of industries (Table 3). In particular, they are currently being employed in "red" biotechnology (i.e., biotechnology applied to pharmaceutical and medical fields). Other enzymes such as cellulase, chitinase, esterase, mercuric reductase, and $\beta$-glucosidases are exploited in "grey" (i.e., environmental) biotechnology while lipase is used in "blue" biotechnology, being applied to aquatic organisms and $\beta$-glucosidases and xylanase in biofuel production. 
Table 3. DHAB microbiome as a source of polyextremozymes. The bacterial and archaeal species marked with an asterisk have been isolated from DHABs, whereas the other genera are potentially producers of extremozymes because these have identified from DHABs (but not cultured thus, being isolated from marine and/or other extreme environments)

\begin{tabular}{|c|c|c|c|c|}
\hline Enzyme & Biological Source & Specific Adaptations & Function and/or Applications & Ref. \\
\hline $\begin{array}{l}\text { Aldehyde } \\
\text { dehydrogenase } \\
(\text { EC 1.2.1.3-7) }\end{array}$ & $\begin{array}{l}\text { Bacillus halodurans from Nereus interface; Atlantis } \\
\text { II Red Sea brine pool; Cytophaga sp. KUC-1 from } \\
\text { Antarctic seawater and Halobacterium salinarum }\end{array}$ & $\begin{array}{l}\text { Slight halophile; thermo- } \\
\text { and psychrophilic }\end{array}$ & $\begin{array}{l}\text { Biotransformation of a large number of drugs and } \\
\text { other xenobiotics generates aldehydes as } \\
\text { intermediates or as products resulting from } \\
\text { oxidative deaminations }\end{array}$ & [172-175] \\
\hline $\begin{array}{l}\text { Protease } \\
\text { (EC 3.4.21-25) }\end{array}$ & $\begin{array}{l}\text { Salinivibrio costicola* and Pseudoalteromonas } \\
\text { ruthenica* from Erba DHAB. Bacillus circulans } \\
\text { BM15 and PseudoAlteromonas sp. 129-1. Bacillus sp. } \\
\text { NPST-AK1, Halobacterium halobium (ATCC 43214), } \\
\text { Bacillus licheniformis, Bacillus halophilus, } \\
\text { Pseudoalteromonas strain EB27, Halomonas meridiana } \\
\text { DSM 5425, Bacillus sp. (Ve2-20-91 (HM047794)), } \\
\text { and Bacillus caseinilyticus }\end{array}$ & $\begin{array}{l}\text { Haloalkaliphilic and } \\
\text { thermotolerant alkaline }\end{array}$ & $\begin{array}{l}\text { Protein hydrolysis finds a broad variety of } \\
\text { potential applications in diverse biotechnological } \\
\text { processes such as in the feed, food, pharmacology } \\
\text { (anticancer and antihemolytic activity) and } \\
\text { cosmetic (keratin-based preparation) industries, } \\
\text { and cleaning processes (e.g., detergent additive) }\end{array}$ & [176-185] \\
\hline $\begin{array}{l}\text { Cellulase } \\
\text { (EC 3.2.1.4) }\end{array}$ & $\begin{array}{l}\text { Cytophaga hutchinsonii, Halorhabdus tiamatea } \\
\text { from Shaban DHAB, Bacillus sp. SR22 from } \\
\text { seawater, Bacillus sp., Vibrio sp., Rhodococcus sp., } \\
\text { Clostridium and Streptomyces from mangrove } \\
\text { Halorhabdus utahensis from Great Salt Lake }\end{array}$ & $\begin{array}{l}\text { Halo-alkali tolerant and } \\
\text { thermotolerant }\end{array}$ & $\begin{array}{l}\text { Breakdown of cellulose-producing } \\
\text { polysaccharides; potential application in the food, } \\
\text { animal feed, beer and wine, textile and laundry, } \\
\text { and pulp and paper industries, agriculture, biofuel, } \\
\text { pharmaceutical industries, and waste management }\end{array}$ & [186-191] \\
\hline $\begin{array}{l}\text { Chitinase (EC 3.2.1.14), } \\
\text { chitin deacetylase (EC } \\
\text { 3.5.1.41) }\end{array}$ & $\begin{array}{l}\text { Bacillus thuringiensis HBK- } 51 \text { from soil. } \\
\text { PseudoAlteromonas sp. DC14, Vibrio cholerae, Vibrio } \\
\text { parahaemolyticus, and Arthrobacter sp. AW19M34-1 } \\
\text { from seawater }\end{array}$ & $\begin{array}{l}\text { Halo-alkali tolerant and } \\
\text { thermotolerant }\end{array}$ & $\begin{array}{l}\text { Hydrolysis of chitin and hence N-acetyl chitobiose } \\
\text { production which in turn can be useful in } \\
\text { fermentation research and biomedicine. There } \\
\text { have also been applications in the cosmetic and } \\
\text { pharmaceutic fields }\end{array}$ & [192-194] \\
\hline $\begin{array}{l}\text { Esterase } \\
\text { (EC 3.1.1.1) }\end{array}$ & $\begin{array}{l}\text { Zunongwangia profunda* from Atlantis II and } \\
\text { Nereus interface and brine pools. Alcanivorax } \\
\text { dieselolei B5(T) from Erba interface. Bacillus cereus } \\
\text { AGP-03 from hot spring. Archaeoglobus fuloidus }\end{array}$ & $\begin{array}{l}\text { Thermo-halotolerant and } \\
\text { metal resistant; cold-active } \\
\text { and organic solvent-tolerant }\end{array}$ & $\begin{array}{l}\text { Leather manufacturing, flavor development in the } \\
\text { dairy industry, oil biodegradation, and the } \\
\text { synthesis of pharmaceuticals and chemicals }\end{array}$ & [195-200] \\
\hline $\begin{array}{l}\text { Ferredoxin } \\
\text { oxidoreductase } \\
\text { (EC 1.2.7.1) }\end{array}$ & $\begin{array}{l}\text { Halorhabdus tiamatea SARL4BT* from Shaban } \\
\text { DHAB. Desulfovibrio sp. from Atlantis II DHAB. } \\
\text { Methanosarcina barkeri }\end{array}$ & Low-oxygen tolerant & $\begin{array}{l}\text { Oxidation/reduction processes which are applied } \\
\text { in the asymmetric oxyfunctionalization of steroids } \\
\text { and other pharmaceuticals, synthesis and } \\
\text { modification of polymers, oxidative degradation } \\
\text { of pollutants, oxyfunctionalization of } \\
\text { hydrocarbons, and the construction of biosensors } \\
\text { for diverse clinical applications }\end{array}$ & {$[189,201,202]$} \\
\hline
\end{tabular}


Table 3. Cont

\begin{tabular}{|c|c|c|c|c|}
\hline Enzyme & Biological Source & Specific Adaptations & Function and/or Applications & Ref. \\
\hline $\begin{array}{l}\text { Lipase } \\
\text { (EC 3.1.1.3) }\end{array}$ & $\begin{array}{l}\text { Idiomarina sp. W33, HaloBacillus sp., and } \\
\text { Archaeoglobus fulgidus. Marinobacter alkaliphilus } \\
\text { ABN-IAUF-1. Bacillus sp., Arthrobacter sp., } \\
\text { Pseudomonas sp., and Psychrobacter sp. from } \\
\text { Antarctic marine sediments. Oceano Bacillus sp. } \\
\text { PUMB02 from seawater }\end{array}$ & $\begin{array}{l}\text { Halo- alkalitolerant and } \\
\text { hyperthermophilic }\end{array}$ & $\begin{array}{l}\text { Hydrolysis of acylglycerols to release fatty acids } \\
\text { and lower acylglycerols or glycerol. Lipase } \\
\text { enzymes are exploited in the food, beverage, } \\
\text { detergent, biofuel production, animal feed, textiles, } \\
\text { leather, paper processing, and cosmetic industries }\end{array}$ & [203-208] \\
\hline $\begin{array}{l}\text { Mercuric reductase } \\
\text { (EC 1.16.1.1) }\end{array}$ & $\begin{array}{l}\text { Atlantis II deep-sea brine. Chromohalobacter } \\
\text { israelensis* from Erba and Atlantis II DHABs. } \\
\text { Bacillus firmus* from Discovery DHAB }\end{array}$ & $\begin{array}{l}\text { Extreme halophilic and } \\
\text { thermophilic }\end{array}$ & $\begin{array}{l}\text { This enzyme can convert toxic mercury ions into } \\
\text { relatively inert elemental mercury. It is very useful } \\
\text { in waste-water treatments }\end{array}$ & {$[209,210]$} \\
\hline $\begin{array}{l}\text { Nitrilase } \\
\text { (EC 3.5.5.1) }\end{array}$ & Red Sea Atlantis II brine & $\begin{array}{l}\text { Thermostable and heavy } \\
\text { metal tolerant }\end{array}$ & $\begin{array}{l}\text { Nitrilase can hydrolyze a single cyano group in } \\
\text { dinitriles or polynitriles, yelding cyanocarboxilic } \\
\text { acids, which are used in different kinds of } \\
\text { industries, including the food and pharmacology } \\
\text { industries; also used for bioremediative purposes }\end{array}$ & [211] \\
\hline $\begin{array}{l}\text { Pullulanase } \\
\text { (EC 3.2.1.41) }\end{array}$ & Bacillus sp. and Streptomyces sp. & Alkaliphilic & $\begin{array}{l}\text { Utilized to hydrolyze the } \alpha-1,6 \text { glucosidic linkages } \\
\text { in starch, enabling a complete and efficient } \\
\text { conversion of the branched polysaccharides into } \\
\text { small fermentable sugars during the } \\
\text { saccharification process }\end{array}$ & [212] \\
\hline $\begin{array}{l}\text { Xylanase (EC 3.2.1.8) } \\
\text { and } \beta \text {-Xylosidase } \\
(\text { EC 3.2.1.37) }\end{array}$ & $\begin{array}{l}\text { Staphylococcus sp., Arthrobacter sp., Streptomyces sp., } \\
\text { and Vibrio sp. XY-214 from seawater. } \\
\text { Oceanospirillum linum CL8 and Halorhabdus } \\
\text { utahensis from Great Salt Lake. Halorhabdus } \\
\text { tiamatea SARL4BT* from Shaban DHAB. } \\
\text { Pseudoalteromonas mariniglutinosa* from Erba and } \\
\text { Nereus DHAB. Marinimicrobium haloxylanilyticum* } \\
\text { from Kebrit DHAB. Zunongwangia profunda* from } \\
\text { Nereus and Atlantis II DHABs. Halomonas } \\
\text { meridiana* from Bannock, Erba, and Nereus } \\
\text { DHABs. Bacillus halodurans* from Nereus interface }\end{array}$ & $\begin{array}{l}\text { Alkali-halotolerant and } \\
\text { psychrophilic }\end{array}$ & $\begin{array}{l}\text { Commercial exploitation in the areas of the food, } \\
\text { feed, and paper and pulp industries; also used to } \\
\text { increase sugar recovery from agricultural residues } \\
\text { for biofuel production }\end{array}$ & {$[189,213-218]$} \\
\hline $\begin{array}{l}\alpha \text {-agarase } \\
(\text { EC 3.2.1.158) and } \\
\beta \text {-agarase } \\
(\text { EC 3.2.1.81) }\end{array}$ & $\begin{array}{l}\text { Alteromonas macleodit* from Erba, Discovery, and } \\
\text { Nereus DHABs. Alteromonas sp. GNUM-1, } \\
\text { Alteromonas agarlyticus, Alteromonas sp. strain C-1, } \\
\text { Vibrio sp. PO-303, Altermonas sp. SY } 37-12 \text {, and } \\
\text { Cytophaga flevensis from seawater and marine } \\
\text { sediments }\end{array}$ & Moderate halophile & $\begin{array}{l}\text { Degradation of agar-degrading bacteria used as } \\
\text { oriental food; wide applications in the food } \\
\text { industry, cosmetics, and medical fields, and as a } \\
\text { tool enzyme for biological, physiological, and } \\
\text { cytological studies }\end{array}$ & [219-221] \\
\hline
\end{tabular}


Table 3. Cont

\begin{tabular}{|c|c|c|c|c|}
\hline Enzyme & Biological Source & Specific Adaptations & Function and/or Applications & Ref. \\
\hline $\begin{array}{l}\alpha \text {-amylase } \\
(\text { EC 3.2.1.1) }\end{array}$ & $\begin{array}{l}\text { PontiBacillus chungwhensis* from Discovery DHAB. } \\
\text { Halomonas meridiana* from Nereus, Erba, and } \\
\text { Bannock DHABs. Zunongwangia profunda* from } \\
\text { Atlantis II and Nereus DHABs. Cytophaga sp. } \\
\text { HaloBacillus sp., Bacillus sp. GM8901, Bacillus sp. } \\
\text { TSCVKK, and Methanococcus jannaschii. } \\
\text { Halobacterium sp. from hypersaline environment. } \\
\text { Alteromonas haloplanctis from Antarctic seawater }\end{array}$ & $\begin{array}{l}\text { Moderate halophile and } \\
\text { alkali- tolerant; } \\
\text { hyperthermophilic }\end{array}$ & $\begin{array}{l}\alpha \text {-amylase has implications in the food, } \\
\text { pharmaceutical, and chemical industries; } \\
\text { multifunctional amylase exhibits } \\
\text { transglycosylation and hydrolysis activities to } \\
\text { produce isomaltooligosaccharides, } \\
\text { maltooligosaccharides and glucose }\end{array}$ & [222-232] \\
\hline $\begin{array}{l}\beta \text {-glucosidases } \\
\text { (EC 3.2.1.21) }\end{array}$ & $\begin{array}{l}\text { Halorhabdus tiamatea SARL4BT* from Shaban } \\
\text { DHAB. Alteromonas sp. L82 from the Mariana } \\
\text { Trench. Cytophaga hutchinsonii }\end{array}$ & $\begin{array}{l}\text { Low-oxygen tolerant, } \\
\text { cold-adapted, and } \\
\text { salt-tolerant }\end{array}$ & $\begin{array}{l}\beta \text {-glucosidases convert cellobiose and short } \\
\text { cellodextrins into glucose. } \beta \text {-glucosidases are } \\
\text { widely used in the production of biofuels and } \\
\text { ethanol from cellulosic agricultural wastes, in the } \\
\text { production of wine, and in the flavor industry. } \\
\text { They can cleave phenolic and phytoestrogen } \\
\text { glucosides from fruits and vegetables for } \\
\text { extracting medicinally important compounds and } \\
\text { enhancing the quality of beverages }\end{array}$ & $\begin{array}{l}{[189,191,233,} \\
234]\end{array}$ \\
\hline $\begin{array}{l}\text { K-Carragenases } \\
\text { (EC 3.2.1.83) }\end{array}$ & $\begin{array}{l}\text { Pseudoalteromonas carrageenovora* from Erba } \\
\text { sediments. Bacillus sp. Alteronomonas sp., } \\
\text { Cytophaga sp., and PseudoAlteromonas sp. } \\
\text { Pseudomonas sp., Vibrio } s p \text {. NJ-2, and Vibrio } \\
\text { parahaemolyticus from seawater }\end{array}$ & Alkali-halotolerant & $\begin{array}{l}\text { Production of oligosaccharides with potential } \\
\text { applications in the biomedical field, in bioethanol } \\
\text { production, in the textile industry, and as a } \\
\text { detergent additive }\end{array}$ & [235-237] \\
\hline $\begin{array}{l}\text { Cyclodextrin } \\
\text { glycosyltransferase } \\
\text { (EC 2.4.1.19) }\end{array}$ & Bacillus lehensis* from Discovery DHAB & Alkali-halotolerant & $\begin{array}{l}\text { Cyclodextrins produced by this enzyme have } \\
\text { broad, non-toxic applications in the } \\
\text { pharmaceutical, cosmetic, and food industries }\end{array}$ & {$[66,238]$} \\
\hline
\end{tabular}


For instance, the production of novel thermoactive and alkali-tolerant $\alpha$-amylases has been documented for many prokaryotic species such as Pontibacillus chungwhensis, Halomonas meridiana, and Zunongwangia profunda isolated taxa from DHABs. This group of enzymes has a very wide spectrum of industrial application, including in the sugar production, animal nutrition, baking, brewing, and distilling industries, in the production of digestive aids, in the pharmaceutical industries, and in the production of biofuel [239]. Amylases are consistently the most important among the enzymes of industrial interest and are forecasted to reach US $\$ 6.2$ billion by 2020 [240]. For this reason, there is noteworthy attention paid to extremophilic $\alpha$-amylases that have activity and stability characteristics suitable for the harsh conditions, including extreme salinity $(2-4 \mathrm{M} \mathrm{NaCl})$ and elevated temperature $\left(80^{\circ} \mathrm{C}\right)$, demanded by industrial activities [241].

Interestingly, nitrilases have also been identified in DHABs, and are employed as commercial biocatalysts for the synthesis of plastics, paints, and fibers in the chemical industries and are also employed in the pharmaceutical industries for the manufacturing of (S)-ibuprofen, a widely used non-steroidal anti-inflammatory drug [242]. Moreover, nitrilases can detoxify cyanide present within wastes and degrade herbicides, representing an enzyme of extreme importance in bioremediation [243]. Biotransformation using native organisms as catalysts tends to be insufficient because the amount of nitrilases present as total cellular proteins is very low, and the reaction rate is slow and unstable [244]. Thus, the nitrilase recently identified by metagenomes mining in the Atlantis II DHAB could represent a valuable alternative not only for its thermal stability and tolerance to heavy metals compared to closely related nitrilases but also for the great number of microorganisms which could possess and produce these enzymes [211]. Another example of utilising sequence-based and activity-based metagenomics in mining for potential industrial biocatalysts is the esterase EstATII collected from the Atlantis II basin in the Red Sea, which displays a combination of extremophilic properties [197]. This enzyme is thermophilic (optimum temperature $65^{\circ} \mathrm{C}$ ) and halotolerant (for up to $4.5 \mathrm{M} \mathrm{NaCl}$ ) and maintains significant activity in the presence of a wide variety of toxic heavy metals, making it a potentially useful biocatalyst [197]. In agreement with this study, O.16 esterase was identified in the Urania basin which shoswed remarkable polyextremophilic properties (i.e., 180 $\times$ enhanced activity at 2 to $4 \mathrm{M} \mathrm{NaCl}$ and functioning at $40 \mathrm{MPa}$ [198]). This enzyme also displayed increased activity when dissolved in $70 \%$ ethanol or n-propanol and extraordinarily high enantioselectivity in hydrolysis and transesterification of compounds important in the pharmaceutical, cosmetic, and food industries $[198,245]$. Thus, DHABs seem to be a suitable habitat for mining esterases which are potentially useful for industrial biotransformation, considering the great size of the lipolytic enzyme market, which is valued at the billion-dollar mark in the world's market [246].

A study conducted on bacterial strains isolated from haloclines of Urania, Bannock, Discovery, and L'Atalante showed that Bacillus horneckiae gave highly stereoselective reduction for racemic propyl ester of anti-2- oxotricyclo[2.2.1.0]heptan-7-carboxylic acid (R,S)-1, a key intermediate of the synthesis of D-cloprostenol (chemical analog of prostaglandin [66]). Another isolate of Halomonas aquamarina was found to enantioselectively hydrolyze this molecule, indicating the potential of DHAB extremophile microbiome and marine-derived esterases and ketoreductases in stereoselective biocatalysis [66]. The same authors also isolated Bacillus lehensis from Discovery DHABs which harness an alkali-tolerant cyclodextrin glycosyltransferase and are able to produce non-toxic products for the pharmaceutical, cosmetic, and food industries.

Overall, DHABs seem to be a suitable habitat for mining novel biocatalyst enzymes which are potentially useful for industrial biotransformations, encouraging further scientific challenges and research for fully realising the potential of DHAB extremozymes.

\subsection{DHAB-Derived Prokaryotes: Promising Candidates for Enhanced Bioremediation of Oil Hydrocarbons}

Petroleum hydrocarbons are among the most widespread pollutants on our planet and are becoming a severe problem because of their causing harmful damage to the environment and human health $[247,248]$. Oil pollution can occur in the environment following either catastrophic accidents 
(shipping disasters or pipeline failures) or natural oil seepages and biota [249]. Such contaminants can exert carcinogenic, neurotoxic, and mutagenic effects when organisms are exposed to them, significantly impacting the environment [250-252]. For these reasons, many innovative technologies have been developed for the clean-up of oil-polluted areas [247]. One of the most reliable of these is certainly bioremediation, which exploits the metabolic capabilities of microorganisms to break down recalcitrant hydrocarbons into harmless by-products, thus minimising the impact on the environment [253]. It is a more environmentally friendly alternative when compared with classical remediation techniques, which allow the reduction from the environment of a vast array of pollutants [254].

Most petroleum hydrocarbons encountered in the environment can be degraded or metabolized by indigenous bacteria which have developed specific pathways for sustaining their energetic and carbon requirements for living and blooming in the presence of these contaminants [255,256]. Indeed, many studies have focused their attention on hydrocarbon-degrading bacteria in oil-rich environments, including oil spill areas and oil reservoirs [257], and have demonstrated that their abundance is closely related to the respective types of petroleum hydrocarbons and surrounding environmental factors [258-261]. Despite this, many other normal and extreme microorganisms have been isolated and employed as biodegraders for dealing with petroleum hydrocarbons, representing a promising biotechnological alternative for achieving oil-hydrocarbon degradation $[9,262]$. Because of the particular physiological characteristics of microorganisms isolated from extreme environments, including DHABs, prokaryotes can be employed for enhanced bioremediation of oil hydrocarbons, especially in hypersaline environments $[263,264]$. For instance, members of the genera Alcanivorax and Marinobacter, which have been isolated respectively from Erba halocline and Shaban Deep [70,84], are essential marine hydrocarbonoclastic bacteria present in the active phase of oil spills, playing a significant role in the natural remediation of oil-polluted marine environments all over the world [265-267]. Their number increases very quickly after oil spills, although it declines only a few weeks later (see [268] as well as references therein). The outstanding bioremediation capacity of $A$. dieselolei has also been supported by sequencing the genome of the strain KS-293 isolated from surface seawater [269]. Its genome consistently contains multiple genes and enzymes involved in pathways associated with hydrocarbon degradation (linear and branched alkanes) and shows high similarity with A. dieselolei strain B5 [270-272]. This strain has been observed to preserve cell integrity under pressures of up to $10 \mathrm{MPa}$ cultured with n-dodecane as a sole carbon source, downregulating $95 \%$ of its genes [273,274]. Additionally, Sass et al., 2008 demonstrated that the strain DS-1, closely related to Bacillus aquimaris, isolated from the Discovery $\mathrm{DHAB}$, could grow with n-alkanes (n-dodecane and n-hexadecane) in the presence of $12-20 \% \mathrm{NaCl}$ [275]. Furthermore, Salinisphaera shabanensis and Marinobacter salsuginis have been isolated from the Shaban Deep, displaying a high capacity to assimilate aliphatic hydrocarbons [70,276]. S. shabanensis can be cultured at a wide range of salinity and temperatures $\left(0.2-4.8 \mathrm{M} \mathrm{NaCl}\right.$ and $\left.5-42{ }^{\circ} \mathrm{C}\right)$, on a vast array of substrates including $\mathrm{n}$-alkanes (dodecane). M. salsuginis is a heterotrophic, facultative anaerobic bacterium capable of fermentation and nitrate reduction [70].

Moreover, other bacteria belonging to the genus Marinobacteria and isolated from seawater and Nereus halocline have shown to be efficient for bioremediation purposes for degrading hydrocarbons, including polycyclic aromatic hydrocarbons (PAHs), as revealed by the complete genome sequence of Marinobacter flavimaris SW-145 [277-280]. Other strains belonging to the genera Vibrio, Pseudomonas, Arthrobacter Pseudoalteromonas, Idiomarina, Halomonas, and Thalassospira identified in different DHABs have been collected and cultured from marine sediments and are able to grow on PAHs including naphthalene, dibenzothiophene, pyrene, and phenanthrene [21,39,267,281,282].

Even though many oil hydrocarbons can be easily degraded in low salinity marine habitats [267], very little is known about their fate in moderate and in hypersaline environments where microbial activity is enormously inhibited [263,283]. To this purpose, some archaea belonging to the class of Halobacteria identified in many DHABs hold great promise and have considerable potential to bioremediate hydrocarbons in high salty environments such as nearshore oil production sites, salt marshes, sabkhas, and other coastal flats, including industrial wastewaters [264,284]. 
Haloarchaea of the class Halobacteria identified in many DHABs located both in the Mediterranean and the Red Sea $[17,44,56,189]$ can produce PAH-degrading enzymes, which may be exploited to remove aromatic hydrocarbons from the polluted environments safely [285]. In the hypersaline coastal areas of Kuwait, hydrocarbonoclastic haloarchaea, together with $M$. flavimaris, a diazotrophic strain able to grow under $1 \mathrm{M}-3.5 \mathrm{M} \mathrm{NaCl}$ conditions, have effectively contributed to oil bioremediation [286].

Although more archaeal strains have been isolated, our information on the physiological, biochemical, and genomic basis of hydrocarbon degradation by members of the Halobacteria is still extremely scant $[263,287]$. Such information is crucial for designing novel and more efficient technologies employing haloarchaea for the remediation of contaminated high salinity environments.

\section{Conclusions and Future Directions}

Polyextremophilic bacteria and archaea are an extraordinary reservoir of novel enzymes and bioactive molecules which can provide important benefits for different biotechnological applications, ranging from medicine to environmental fields. So far, studies on DHABs are limited, and we urgently need to expand data on microbial diversity and ecology of these extreme ecosystems. The uniqueness of these habitats is able to select for highly specialized organisms which show extreme adaptions at morphological, physiological, biochemical, and genetic levels, hinting at a bright future for "blue" biotechnology. In this extensive literature review we have observed that polyextremophiles maintain several high metabolic similarities to other non-extreme prokaryotes. This important issue, which remains to be further investigated, could open new research perspectives on the production of the biomolecules' portfolio of marine microorganisms. Such explorations are expected to provide huge rewards not only in terms of the impact on existing industries for the discovery of new products with beneficial or useful properties, but also in the "blue" economy. This scenario is also perfectly framed within the Sustainable Development Goals of the United Nations, which aims to identify actual solutions for disease outbreaks, climate change, and environmental degradation in order to have safer, cleaner, and more efficient industrial manufacturing processes in order to improve human health and wellbeing from a sustainable development perspective.

Nowadays, "blue" biotechnologies are taking advantage of increasing numbers of "-omics" tools and high-throughput screenings for unveiling the chemical diversity of the extreme environments present in the oceans. These tools are facilitating the identification of prokaryotic metabolic adaptations, which can lead to the production of novel molecules and thus can be exploited for the development of new biotechnologies. To date, novel uncultured species identified in DHABs of the genera Streptomyces, Pseuodalteromonas, and Bacillus seem to hold great potential in producing new bioactive molecules. Among the culturable species identified in DHABs, Chromohalobacter israelensis, Zunongwangia profunda, Marinobacter flavimaris, Alcanivorax dieselolei, Halomonas meridiana, Alteromonas macleodii, and Bacillus halodurans are promising species for biotechnological applications. Further innovative technologies and studies applied to DHABs will be essential to carry out in-depth investigations and to disentangle microbial assemblages, functions, and metabolites of biotechnological interest from these peculiar systems. Thus, the actual development of DHAB-derived biotechnologies will depend on technological and methodological advancements and the ability of scientists to promote research projects for the study of these ecosystems.

Supplementary Materials: The following information is available online at http://www.mdpi.com/1660-3397/18/ 2/91/s1, Table S1: Prokaryotic strains isolated from DHABs, Table S2: Prokaryotic strains isolated from DHABs and their closest relatives obtained from phylogenetic analyses.

Author Contributions: C.C. conceived the study. S.V. conducted literature analysis and M.T. performed bioinformatic analyses on the available data. C.C., S.V., and M.T. contributed to data interpretation. S.V., C.C., and M.T. wrote the manuscript. All authors have read and agreed to the published version of the manuscript.

Funding: This research was funded by University Scientific Research, the Italian Ministry for Education, University, and Research (MIUR).

Conflicts of Interest: The authors declare that they have no conflict of interest. 


\section{References}

1. Danovaro, R.; Corinaldesi, C.; Dell'Anno, A.; Snelgrove, P.V.R. The deep-sea under global change. Curr. Biol. 2017, 27, R461-R465. [CrossRef] [PubMed]

2. Danovaro, R.; Snelgrove, P.V.R.; Tyler, P. Challenging the paradigms of deep-sea ecology. Trends Ecol. Evol. 2014, 29, 465-475. [CrossRef] [PubMed]

3. Herring, P.J. The biology of the deep ocean; Oxford University Press: New York, NY, USA, 2001; pp. 1-25.

4. Bartlett, D.H. Microbial Life in the Trenches. Mar. Technol. Soc. J. 2009, 43, 128-131. [CrossRef]

5. Jørgensen, B.B.; Boetius, A. Feast and famine - Microbial life in the deep-sea bed. Nat. Rev. Microbiol. 2007, 5, 770-781. [CrossRef]

6. Ramirez-Llodra, E.; Brandt, A.; Danovaro, R.; De Mol, B.; Escobar, E.; German, C.R.; Levin, L.A.; Martinez Arbizu, P.; Menot, L.; Buhl-Mortensen, P.; et al. Deep, diverse and definitely different: Unique attributes of the world's largest ecosystem. Biogeosciences 2010, 7, 2851-2899. [CrossRef]

7. Merino, N.; Aronson, H.S.; Bojanova, D.P.; Feyhl-Buska, J.; Wong, M.L.; Zhang, S.; Giovannelli, D. Living at the extremes: Extremophiles and the limits of life in a planetary context. Front. Microbiol. 2019, 10, 1-25. [CrossRef]

8. Merlino, G.; Barozzi, A.; Michoud, G.; Ngugi, D.K.; Daffonchio, D. Microbial ecology of deep-sea hypersaline anoxic basins. FEMS Microbiol. Ecol. 2018, 94, 1-15. [CrossRef]

9. Barone, G.; Varrella, S.; Tangherlini, M.; Rastelli, E.; Dell'Anno, A.; Danovaro, R.; Corinaldesi, C. Marine Fungi: Biotechnological Perspectives from Deep-Hypersaline Anoxic Basins. Diversity 2019, 11, 113. [CrossRef]

10. Jongsma, D.; Fortuin, A.R.; Huson, W.; Troelstra, S.R.; Klaver, G.T.; Peters, J.M.; Van Harten, D.; De Lange, G.J.; Ten Haven, L. Discovery of an anoxic basin within the strabo trench, eastern mediterranean. Nature 1983, 305, 795-797. [CrossRef]

11. Camerlenghi, A. Anoxic basins of the eastern Mediterranean: Geological framework. Mar. Chem. 1990, 31, 1-19. [CrossRef]

12. Hartmann, M.; Scholten, J.C.; Stoffers, P.; Wehner, F. Hydrographic structure of brine-filled deeps in the Red Sea - new results from the Shaban, Kebrit, Atlantis II, and Discovery Deep. Mar. Geol. 1998, 144, 311-330. [CrossRef]

13. Pautot, G.; Guennoc, P.; Coutelle, A.; Lyberis, N. Discovery of a large brine deep in the northern Red Sea. Nature 1984, 310, 133-136. [CrossRef]

14. Backer, H.; Schoell, M. New Deeps with Brines and Metalliferous Sediments in the Red Sea. Nat. Phys. Sci. 1972, 240, 153-158. [CrossRef]

15. Shokes, R.F.; Trabant, P.K.; Presley, B.J.; Reid, D.F. Anoxic, hypersaline basin in the northern Gulf of Mexico. Science 1977, 4297, 1443-1446. [CrossRef] [PubMed]

16. La Cono, V.; Smedile, F.; Bortoluzzi, G.; Arcadi, E.; Maimone, G.; Messina, E.; Borghini, M.; Oliveri, E.; Mazzola, S.; L'Haridon, S.; et al. Unveiling microbial life in new deep-sea hypersaline Lake Thetis. Part I: Prokaryotes and environmental settings. Environ. Microbiol. 2011, 13, 2250-2268. [CrossRef] [PubMed]

17. Yakimov, M.M.; La Cono, V.; Spada, G.L.; Bortoluzzi, G.; Messina, E.; Smedile, F.; Arcadi, E.; Borghini, M.; Ferrer, M.; Schmitt-Kopplin, P.; et al. Microbial community of the deep-sea brine Lake Kryos seawater-brine interface is active below the chaotropicity limit of life as revealed by recovery of mRNA. Environ. Microbiol. 2015, 17, 364-382. [CrossRef]

18. La Cono, V.; Bortoluzzi, G.; Messina, E.; La Spada, G.; Smedile, F.; Giuliano, L.; Borghini, M.; Stumpp, C.; Schmitt-Kopplin, P.; Harir, M.; et al. The discovery of Lake Hephaestus, the youngest athalassohaline deep-sea formation on Earth. Sci. Rep. 2019, 9, 1679. [CrossRef]

19. Mapelli, F.; Barozzi, A.; Michoud, G.; Merlino, G.; Crotti, E.; Borin, S.; Daffonchio, D. An updated view of the microbial diversity in deep hypersaline anoxic basins. In Adaption of Microbial Life to Environmental Extremes; Stan-Lotter, H., Fendrihan, S., Eds.; Springer International Publishing: Cham, Switzerland, 2017; pp. $23-40$. ISBN 9783319483276.

20. Eder, W.; Ludwig, W.; Huber, R. Novel 16S rRNA gene sequences retrieved from highly saline brine sediments of Kebrit Deep, Red Sea. Arch. Microbiol. 1999, 172, 213-218. [CrossRef]

21. Daffonchio, D.; Borin, S.; Brusa, T.; Brusetti, L.; van der Wielen, P.W.J.J.; Bolhuis, H.; Yakimov, M.M.; D'Auria, G.; Giuliano, L.; Marty, D.; et al. Stratified prokaryote network in the oxic-anoxic transition of a deep-sea halocline. Nature 2006, 440, 203-207. [CrossRef] 
22. Yakimov, M.M.; La Cono, V.; Denaro, R.; D’Auria, G.; Decembrini, F.; Timmis, K.N.; Golyshin, P.N.; Giuliano, L. Primary producing prokaryotic communities of brine, interface and seawater above the halocline of deep anoxic lake L'Atalante, Eastern Mediterranean Sea. ISME J. 2007, 1, 743-755. [CrossRef]

23. Borin, S.; Brusetti, L.; Mapelli, F.; D’Auria, G.; Brusa, T.; Marzorati, M.; Rizzi, A.; Yakimov, M.; Marty, D.; De Lange, G.J.; et al. Sulfur cycling and methanogenesis primarily drive microbial colonization of the highly sulfidic Urania deep hypersaline basin. Proc. Natl. Acad. Sci. USA 2009, 106, 9151-9156. [CrossRef] [PubMed]

24. Joye, S.B.; MacDonald, I.R.; Montoya, J.P.; Peccini, M. Geophysical and geochemical signatures of Gulf of Mexico seafloor brines. Biogeosciences 2005, 2, 295-309. [CrossRef]

25. Cita, M.B. Exhumation of Messinian evaporites in the deep-sea and creation of deep anoxic brine-filled collapsed basins. Sediment. Geol. 2006, 188-189, 357-378. [CrossRef]

26. Hsü, K.J.; Cita, M.B.; Ryan, W.B.F. The origin of the Mediterranean evaporites. Initial Reports Deep Sea Drill. Proj. 1973, 13, 1203-1231.

27. van der Wielen, P.W.J.J.; Bolhuis, H.; Borin, S.; Daffonchio, D.; Corselli, C.; Giuliano, L.; D'Auria, G.; de Lange, G.J.; Huebner, A.; Varnavas, S.P.; et al. The enigma of prokaryotic life in deep hypersaline anoxic basins. Science 2005, 307, 121-123. [CrossRef]

28. Barozzi, A.; Mapelli, F.; Michoud, G.; Crotti, E.; Merlino, G.; Molinari, F.; Borin, S.; Daffonchio, D. Microbial Diversity and Biotechnological Potential of Microorganisms Thriving in the Deep-Sea Brine Pools. In Extremophiles From Biology to Biotechnology; Durvasula, R., Rao, D.S., Eds.; CRC Press: Boca Raton, FL, USA; Taylor \& Francis, a CRC title, part of the Taylor \& Francis imprint, a member of the Taylor \& Francis Group, the academic division of T\&F Informa plc: Boca Raton, FL, USA, 2018; pp. 19-32. ISBN 9781498774925.

29. Swift, S.A.; Bower, A.S.; Schmitt, R.W. Vertical, horizontal, and temporal changes in temperature in the Atlantis II and Discovery hot brine pools, Red Sea. Deep. Res. Part I Oceanogr. Res. Pap. 2012, 64. [CrossRef]

30. Ngugi, D.K.; Blom, J.; Alam, I.; Rashid, M.; Ba-Alawi, W.; Zhang, G.; Hikmawan, T.; Guan, Y.; Antunes, A.; Siam, R.; et al. Comparative genomics reveals adaptations of a halotolerant thaumarchaeon in the interfaces of brine pools in the Red Sea. ISME J. 2015, 9, 396-411. [CrossRef]

31. Yakimov, M.M.; La Cono, V.; Slepak, V.Z.; La Spada, G.; Arcadi, E.; Messina, E.; Borghini, M.; Monticelli, L.S.; Rojo, D.; Barbas, C.; et al. Microbial life in the Lake Medee, the largest deep-sea salt-saturated formation. Sci. Rep. 2013, 3, 1-9. [CrossRef]

32. Karbe, L. Hot Brines and the Deep Sea Environment. In Red Sea; Edwards, A.J., Head, S.J., Eds.; Elsevier: Oxford, UK, 1987; pp. 70-89.

33. MacDonald, I.R.; Guinasso, N.L.; Reilly, J.F.; Brooks, J.M.; Callender, W.R.; Gabrielle, S.G. Gulf of Mexico hydrocarbon seep communities: VI. Patterns in community structure and habitat. Geo-Marine Lett. 1990, 10, 244-252. [CrossRef]

34. De Lange, G.J.; Middelburg, J.J.; Van der Weijden, C.H.; Catalano, G.; Luther, G.W.; Hydes, D.J.; Woittiez, J.R.W.; Klinkhammer, G.P. Composition of anoxic hypersaline brines in the Tyro and Bannock Basins, eastern Mediterranean. Mar. Chem. 1990, 31, 63-88. [CrossRef]

35. Van Cappellen, P.; Viollier, E.; Roychoudhury, A.; Clark, L.; Ingall, E.; Lowe, K.; Dichristina, T. Biogeochemical cycles of manganese and iron at the oxic-anoxic transition of a stratified marine basin (Orca Basin, Gulf of Mexico). Environ. Sci. Technol. 1998, 32, 2931-2939. [CrossRef]

36. Schmidt, M.; Al-Farawati, R.; Botz, R. Geochemical Classification of Brine-Filled Red Sea Deeps. In The Red Sea; RasulIan, N.M.A., Stewart, C.F., Eds.; Springer Berlin Heidelberg: Cham, Switzerland, 2015; pp. $219-233$.

37. Stock, A.; Filker, S.; Yakimov, M.; Stoeck, T. Deep Hypersaline Anoxic Basins as Model Systems for Environmental Selection of Microbial Plankton. In Polyextremophiles Life Under Multiple Forms of Stress Life Under Multiple Forms of Stress; Springer Netherlands: Dordrecht, The Netherlands, 2013; pp. 499-515.

38. Eder, W.; Schmidt, M.; Koch, M.; Garbe-Schönberg, D.; Huber, R. Prokaryotic phylogenetic diversity and corresponding geochemical data of the brine-seawater interface of the Shaban Deep, Red Sea. Environ. Microbiol. 2002, 4, 758-763. [CrossRef] [PubMed]

39. Sass, A.M.; Sass, H.; Coolen, M.J.L.; Cypionka, H.; Overmann, J. Microbial Communities in the Chemocline of a Hypersaline Deep-Sea Basin (Urania Basin, Mediterranean Sea). Appl. Environ. Microbiol. 2001, 67, 5392-5402. [CrossRef] [PubMed]

40. van der Wielen, P.W.J.J.; Heijs, S.K. Sulfate-reducing prokaryotic communities in two deep hypersaline anoxic basins in the Eastern Mediterranean deep sea. Environ. Microbiol. 2007, 9, 1335-1340. [CrossRef] 
41. Danovaro, R.; Corinaldesi, C.; Dell'Anno, A.; Fabiano, M.; Corselli, C. Viruses, prokaryotes and DNA in the sediments of a deep-hypersaline anoxic basin (DHAB) of the Mediterranean Sea. Environ. Microbiol. 2005, 7 , 586-592. [CrossRef]

42. Corinaldesi, C.; Tangherlini, M.; Luna, G.M.; Dell'Anno, A. Extracellular DNA can preserve the genetic signatures of present and past viral infection events in deep hypersaline anoxic basins. Proc. R. Soc. B Biol. Sci. 2014, 281, 1-10. [CrossRef]

43. Danovaro, R.; Gambi, C.; Dell'Anno, A.; Corinaldesi, C.; Pusceddu, A.; Neves, R.C.; Kristensen, R.M. The challenge of proving the existence of metazoan life in permanently anoxic deep-sea sediments. BMC Biol. 2016, 14, 1-7. [CrossRef]

44. Pachiadaki, M.G.; Yakimov, M.M.; Lacono, V.; Leadbetter, E.; Edgcomb, V. Unveiling microbial activities along the halocline of Thetis, a deep-sea hypersaline anoxic basin. ISME J. 2014, 8, 2478-2489. [CrossRef]

45. Edgcomb, V.P.; Orsi, W.; Breiner, H.W.; Stock, A.; Filker, S.; Yakimov, M.M.; Stoeck, T. Novel active kinetoplastids associated with hypersaline anoxic basins in the Eastern Mediterranean deep-sea. Deep. Res. Part I Oceanogr. Res. Pap. 2011, 58, 1040-1048. [CrossRef]

46. Alexander, E.; Stock, A.; Breiner, H.W.; Behnke, A.; Bunge, J.; Yakimov, M.M.; Stoeck, T. Microbial eukaryotes in the hypersaline anoxic L'Atalante deep-sea basin. Environ. Microbiol. 2009, 11, 360-381. [CrossRef]

47. Danovaro, R.; Dell'Anno, A.; Pusceddu, A.; Gambi, C.; Heiner, I.; Kristensen, R.M. The first metazoa living in permanently anoxic conditions. BMC Biol. 2010, 8, 30. [CrossRef] [PubMed]

48. Eder, W.; Jahnke, L.L.; Schmidt, M.; Huber, R. Microbial Diversity of the Brine-Seawater Interface of the Kebrit Deep, Red Sea, Studied via 16S rRNA Gene Sequences and Cultivation Methods. Appl. Environ. Microbiol. 2001, 67, 3077-3085. [CrossRef] [PubMed]

49. Cavalazzi, B.; Barbieri, R.; Gómez, F.; Capaccioni, B.; Olsson-Francis, K.; Pondrelli, M.; Rossi, A.P.; Hickman-Lewis, K.; Agangi, A.; Gasparotto, G.; et al. The Dallol Geothermal Area, Northern Afar (Ethiopia)—An Exceptional Planetary Field Analog on Earth. Astrobiology 2019, 19, 553-578. [CrossRef] [PubMed]

50. Poli, A.; Finore, I.; Romano, I.; Gioiello, A.; Lama, L.; Nicolaus, B. Microbial Diversity in Extreme Marine Habitats and Their Biomolecules. Microorganisms 2017, 5, 25. [CrossRef]

51. Gunde-Cimerman, N.; Plemenitaš, A.; Oren, A. Strategies of adaptation of microorganisms of the three domains of life to high salt concentrations. FEMS Microbiol. Rev. 2018, 42, 353-375. [CrossRef]

52. Giddings, L.-A.; Newman, D.J. Bioactive Compounds from Extremophiles. In Bioactive Compounds from Extremophiles; Springer: Cham, Switzerland, 2015; pp. 1-44.

53. Coker, J.A. Extremophiles and biotechnology: Current uses and prospects. F1000Research 2016, 5, 396-403. [CrossRef]

54. Sorokin, D.Y.; Kublanov, I.V.; Gavrilov, S.N.; Rojo, D.; Roman, P.; Golyshin, P.N.; Slepak, V.Z.; Smedile, F.; Ferrer, M.; Messina, E.; et al. Elemental sulfur and acetate can support life of a novel strictly anaerobic haloarchaeon. ISME J. 2016, 10, 240-252. [CrossRef]

55. Kormas, K.A.; Pachiadaki, M.G.; Karayanni, H.; Leadbetter, E.R.; Bernhard, J.M.; Edgcomb, V.P. Inter-comparison of the potentially active prokaryotic communities in the halocline sediments of Mediterranean deep-sea hypersaline basins. Extremophiles 2015, 19, 949-960. [CrossRef]

56. Mwirichia, R.; Alam, I.; Rashid, M.; Vinu, M.; Ba-Alawi, W.; Anthony Kamau, A.; Kamanda Ngugi, D.; Goker, M.; Klenk, H.P.; Bajic, V.; et al. Metabolic traits of an uncultured archaeal lineage-MSBL1-from brine pools of the Red Sea. Sci. Rep. 2016, 6, 1-14. [CrossRef]

57. La Cono, V.; Arcadi, E.; Spada, G.; Barreca, D.; Laganà, G.; Bellocco, E.; Catalfamo, M.; Smedile, F.; Messina, E.; Giuliano, L.; et al. A Three-Component Microbial Consortium from Deep-Sea Salt-Saturated Anoxic Lake Thetis Links Anaerobic Glycine Betaine Degradation with Methanogenesis. Microorganisms 2015, 3, 500-517. [CrossRef]

58. Guan, Y.; Hikmawan, T.; Antunes, A.; Ngugi, D.; Stingl, U. Diversity of methanogens and sulfate-reducing bacteria in the interfaces of five deep-sea anoxic brines of the Red Sea. Res. Microbiol. 2015, 166, 688-699. [CrossRef] [PubMed]

59. Nigro, L.M.; Hyde, A.S.; MacGregor, B.J.; Teske, A. Phylogeography, Salinity Adaptations and Metabolic Potential of the Candidate Division KB1 Bacteria Based on a Partial Single Cell Genome. Front. Microbiol. 2016, 7, 1-9. [CrossRef] [PubMed] 
60. Joye, S.B.; Samarkin, V.A.; Orcutt, B.N.; MacDonald, I.R.; Hinrichs, K.U.; Elvert, M.; Teske, A.P.; Lloyd, K.G.; Lever, M.A.; Montoya, J.P.; et al. Metabolic variability in seafloor brines revealed by carbon and sulphur dynamics. Nat. Geosci. 2009, 2, 349-354. [CrossRef]

61. Stahl, D.A.; de la Torre, J.R. Physiology and Diversity of Ammonia-Oxidizing Archaea. Annu. Rev. Microbiol. 2012, 66, 83-101. [CrossRef]

62. Könneke, M.; Bernhard, A.E.; de la Torre, J.R.; Walker, C.B.; Waterbury, J.B.; Stahl, D.A. Isolation of an autotrophic ammonia-oxidizing marine archaeon. Nature 2005, 437, 543-546. [CrossRef]

63. Oren, A. Molecular ecology of extremely halophilic Archaea and Bacteria. FEMS Microbiol. Ecol. 2002, 39, 1-7. [CrossRef]

64. Oren, A. Life at High Salt Concentrations. In The Prokaryotes; Rosenberg, E., DeLong, E.F., Lory, S., Stackebrandt, E., Thompson, F., Eds.; Springer Berlin Heidelberg: Berlin, Germany, 2013; pp. 421-440.

65. Guan, Y.; Ngugi, D.K.; Vinu, M.; Blom, J.; Alam, I.; Guillot, S.; Ferry, J.G.; Stingl, U. Comparative Genomics of the Genus Methanohalophilus, Including a Newly Isolated Strain From Kebrit Deep in the Red Sea. Front. Microbiol. 2019, 10, 1-11. [CrossRef]

66. De Vitis, V.; Guidi, B.; Contente, M.L.; Granato, T.; Conti, P.; Molinari, F.; Crotti, E.; Mapelli, F.; Borin, S.; Daffonchio, D.; et al. Marine Microorganisms as Source of Stereoselective Esterases and Ketoreductases: Kinetic Resolution of a Prostaglandin Intermediate. Mar. Biotechnol. 2015, 17, 144-152. [CrossRef]

67. Messina, E.; Sorokin, D.Y.; Kublanov, I.V.; Toshchakov, S.; Lopatina, A.; Arcadi, E.; Smedile, F.; La Spada, G.; La Cono, V.; Yakimov, M.M. Complete genome sequence of “Halanaeroarchaeum sulfurireducens" M27-SA2, a sulfur-reducing and acetate-oxidizing haloarchaeon from the deep-sea hypersaline anoxic lake Medee. Stand. Genomic Sci. 2016, 11, 1-15. [CrossRef]

68. Antunes, A.; Taborda, M.; Huber, R.; Moissl, C.; Nobre, M.F.; da Costa, M.S. Halorhabdus tiamatea sp. nov., a non-pigmented extremely halophilic archaeon from a deep-sea hypersaline anoxic basin of the Red Sea, and emended description of the genus Halorhabdus. Int. J. Syst. Evol. Microbiol. 2008, 58, 215-220. [CrossRef]

69. Antunes, A.; Rainey, F.A.; Wanner, G.; Taborda, M.; Pätzold, J.; Nobre, M.F.; da Costa, M.S.; Huber, R. A New Lineage of Halophilic, Wall-Less, Contractile Bacteria from a Brine-Filled Deep of the Red Sea. J. Bacteriol. 2008, 190, 3580-3587. [CrossRef] [PubMed]

70. Antunes, A.; Francça, L.; Rainey, F.A.; Huber, R.; Fernanda Nobre, M.; Edwards, K.J.; da Costa, M.S. Marinobacter salsuginis sp. nov., isolated from the brine-seawater interface of the Shaban Deep, Red Sea. Int. J. Syst. Evol. Microbiol. 2007, 57, 1035-1040. [CrossRef] [PubMed]

71. Edgcomb, V.P.; Pachiadaki, M.G.; Mara, P.; Kormas, K.A.; Leadbetter, E.R.; Bernhard, J.M. Gene expression profiling of microbial activities and interactions in sediments under haloclines of E. Mediterranean deep hypersaline anoxic basins. ISME J. 2016, 10, 2643-2657. [CrossRef] [PubMed]

72. Siam, R.; Mustafa, G.A.; Sharaf, H.; Moustafa, A.; Ramadan, A.R.; Antunes, A.; Bajic, V.B.; Stingl, U.; Marsis, N.G.R.; Coolen, M.J.L.; et al. Unique Prokaryotic Consortia in Geochemically Distinct Sediments from Red Sea Atlantis II and Discovery Deep Brine Pools. PLoS ONE 2012, 7, e42872. [CrossRef] [PubMed]

73. Tortorella, E.; Tedesco, P.; Esposito, F.P.; January, G.G.; Fani, R.; Jaspars, M.; De Pascale, D.; Palma Esposito, F.; January, G.G.; Fani, R.; et al. Antibiotics from deep-sea microorganisms: Current discoveries and perspectives. Mar. Drugs 2018, 16, 355. [CrossRef]

74. Corinaldesi, C.; Barone, G.; Marcellini, F.; Dell'Anno, A.; Danovaro, R. Marine microbial-derived molecules and their potential use in cosmeceutical and cosmetic products. Mar. Drugs 2017, 15, 118. [CrossRef]

75. Lo Giudice, A.; Rizzo, C. Bacteria Associated with Marine Benthic Invertebrates from Polar Environments: Unexplored Frontiers for Biodiscovery? Diversity 2018, 10, 80. [CrossRef]

76. Andryukov, B.; Mikhailov, V.; Besednova, N. The Biotechnological Potential of Secondary Metabolites from Marine Bacteria. J. Mar. Sci. Eng. 2019, 7, 176. [CrossRef]

77. Núñez-Montero, K.; Barrientos, L. Advances in Antarctic Research for Antimicrobial Discovery: A Comprehensive Narrative Review of Bacteria from Antarctic Environments as Potential Sources of Novel Antibiotic Compounds Against Human Pathogens and Microorganisms of Industrial Importance. Antibiotics 2018, 7, 90. [CrossRef]

78. Corinaldesi, C. New perspectives in benthic deep-sea microbial ecology. Front. Mar. Sci. 2015, 2, 1-12. [CrossRef]

79. Kim, S.K. Handbook of Marine biotechnology; Springer-Verlag Berlin Heidelberg: Berlin, Germany, 2015; pp. 307-326. ISBN 9783642539718. 
80. Ferrer, M.; Martínez-Martínez, M.; Bargiela, R.; Streit, W.R.; Golyshina, O.V.; Golyshin, P.N. Estimating the success of enzyme bioprospecting through metagenomics: Current status and future trends. Microb. Biotechnol. 2016, 9, 22-34. [CrossRef] [PubMed]

81. Ziko, L.; Adel, M.; Malash, M.N.; Siam, R. Insights into red sea brine pool specialized metabolism gene clusters encoding potential metabolites for biotechnological applications and extremophile survival. Mar. Drugs 2019, 17, 273. [CrossRef] [PubMed]

82. Ziko, L.; Saqr, A.-H.A.; Ouf, A.; Gimpel, M.; Aziz, R.K.; Neubauer, P.; Siam, R. Antibacterial and anticancer activities of orphan biosynthetic gene clusters from Atlantis II Red Sea brine pool. Microb. Cell Fact. 2019, 18, 56. [CrossRef] [PubMed]

83. Sagar, S.; Esau, L.; Holtermann, K.; Hikmawan, T.; Zhang, G.; Stingl, U.; Bajic, V.B.; Kaur, M. Induction of apoptosis in cancer cell lines by the Red Sea brine pool bacterial extracts. BMC Complement. Altern. Med. 2013, 13, 344. [CrossRef]

84. Esau, L.; Zhang, G.; Sagar, S.; Stingl, U.; Bajic, V.B.; Kaur, M. Mining the deep Red-Sea brine pool microbial community for anticancer therapeutics. BMC Complement. Altern. Med. 2019, 19. [CrossRef]

85. Sagar, S.; Esau, L.; Hikmawan, T.; Antunes, A.; Holtermann, K.; Stingl, U.; Bajic, V.B.; Kaur, M. Cytotoxic and apoptotic evaluations of marine bacteria isolated from brine-seawater interface of the Red Sea. BMC Complement. Altern. Med. 2013, 13, 1-8. [CrossRef]

86. Pruesse, E.; Peplies, J.; Glöckner, F.O. SINA: Accurate high-throughput multiple sequence alignment of ribosomal RNA genes. Bioinformatics 2012, 28, 1823-1829. [CrossRef]

87. Lewis, K.; Epstein, S.; D'Onofrio, A.; Ling, L.L. Uncultured microorganisms as a source of secondary metabolites. J. Antibiot. 2010, 63, 468-476. [CrossRef]

88. Ksouri, R.; Ksouri, W.M.; Jallali, I.; Debez, A.; Magné, C.; Hiroko, I.; Abdelly, C. Medicinal halophytes: Potent source of health promoting biomolecules with medical, nutraceutical and food applications. Crit. Rev. Biotechnol. 2012, 32, 289-326. [CrossRef]

89. Raddadi, N.; Cherif, A.; Daffonchio, D.; Neifar, M.; Fava, F. Biotechnological applications of extremophiles, extremozymes and extremolytes. Appl. Microbiol. Biotechnol. 2015, 99, 7907-7913. [CrossRef]

90. Singh, O.V. Extremophiles; Singh, O.V., Ed.; John Wiley \& Sons, Inc.: Hoboken, NJ, USA, 2012; pp. 1-429. ISBN 9781118394144.

91. Rampelotto, P.H.; Trincone, A. Grand Challenges in Marine Biotechnology; Springer International Publishing: Cham, Switzerland, 2016; pp. 1-260. ISBN 978-3-319-69075-9.

92. Babu, P.; Chandel, A.K.; Singh, O.V. Extremophiles and Their Applications in Medical Processes; SpringerBriefs in Microbiology: Cham, Switzerland, 2015; pp. 1-54. ISBN 978-3-319-12807-8.

93. Shin, D.S.; Pratt, A.J.; Tainer, J.A. Archaeal genome guardians give insights into eukaryotic DNA replication and damage response proteins. Archaea 2014, 2014, 206735. [CrossRef] [PubMed]

94. Majhi, M.C.; Behera, A.K.; Kulshreshtha, N.M.; Mahmooduzafar, D.; Kumar, R.; Kumar, A. ExtremeDB: A Unified Web Repository of Extremophilic Archaea and Bacteria. PLoS ONE 2013, 8. [CrossRef] [PubMed]

95. Cárdenas, J.P.; Valdés, J.; Quatrini, R.; Duarte, F.; Holmes, D.S. Lessons from the genomes of extremely acidophilic bacteria and archaea with special emphasis on bioleaching microorganisms. Appl. Microbiol. Biotechnol. 2010, 88, 605-620. [CrossRef] [PubMed]

96. Land, M.; Hauser, L.; Jun, S.R.; Nookaew, I.; Leuze, M.R.; Ahn, T.H.; Karpinets, T.; Lund, O.; Kora, G.; Wassenaar, T.; et al. Insights from 20 years of bacterial genome sequencing. Funct. Integr. Genomics 2015, 15, 141-161. [CrossRef] [PubMed]

97. Baltz, R.H. Molecular beacons to identify gifted microbes for genome mining. J. Antibiot. 2017, 70, 639-646. [CrossRef] [PubMed]

98. Brown, E.D.; Wright, G.D. Antibacterial drug discovery in the resistance era. Nature 2016, 529, $336-343$. [CrossRef]

99. Holohan, C.; Van Schaeybroeck, S.; Longley, D.B.; Johnston, P.G. Cancer drug resistance: An evolving paradigm. Nat. Rev. Cancer 2013, 13, 714-726. [CrossRef]

100. Ventola, C.L. The antibiotic resistance crisis: Part 1: Causes and threats. P T 2015, 40, 277-283.

101. Housman, G.; Byler, S.; Heerboth, S.; Lapinska, K.; Longacre, M.; Snyder, N.; Sarkar, S. Drug resistance in cancer: An overview. Cancers 2014, 6, 1769-1792. [CrossRef] 
102. Trindade, M.; van Zyl, L.J.; Navarro-Fernández, J.; Elrazak, A.A. Targeted metagenomics as a tool to tap into marine natural product diversity for the discovery and production of drug candidates. Front. Microbiol. 2015, 6, 1-14. [CrossRef]

103. Malve, H. Exploring the ocean for new drug developments: Marine pharmacology. J. Pharm. Bioallied Sci. 2016, 8, 83-91. [CrossRef] [PubMed]

104. Li, B.; Wever, W.J.; Walsh, C.T.; Bowers, A.A. Dithiolopyrrolones: Biosynthesis, synthesis, and activity of a unique class of disulfide-containing antibiotics. Nat. Prod. Rep. 2014, 31, 905-923. [CrossRef] [PubMed]

105. Imada, C.; Maeda, M.; Hara, S.; Taga, N.; Simidu, U. Purification and characterization of subtilisin inhibitors 'Marinostatin' produced by marine Alteromonas sp. J. Appl. Bacteriol. 1986, 60, 469-476. [CrossRef]

106. Gustafson, K.; Roman, M.; Fenical, W. The Macrolactins, a Novel Class of Antiviral and Cytotoxic Macrolides from a Deep-Sea Marine Bacterium. J. Am. Chem. Soc. 1989, 111, 7519-7524. [CrossRef]

107. Nagao, T.; Adachi, K.; Sakai, M.; Nishijima, M.; Sano, H. Novel macrolactins as antibiotic lactones from a marine bacterium. J. Antibiot. 2001, 54, 333-339. [CrossRef]

108. Jaruchoktaweechai, C.; Suwanborirux, K.; Tanasupawatt, S.; Kittakoop, P.; Menasveta, P. New macrolactins from a marine Bacillus sp. Sc026. J. Nat. Prod. 2000, 63, 984-986. [CrossRef]

109. Xue, C.; Tian, L.; Xu, M.; Deng, Z.; Lin, W. A new 24-membered lactone and a new polyene $\delta$-lactone from the marine bacterium Bacillus marinus. J. Antibiot. 2008, 61, 668-674. [CrossRef]

110. Berger, E.; Crampton, M.C.; Nxumalo, N.P.; Louw, M.E. Extracellular secretion of a recombinant therapeutic peptide by Bacillus halodurans utilizing a modified flagellin type III secretion system. Microb. Cell Fact. 2011, 10. [CrossRef]

111. Gerard, J.M.; Haden, P.; Kelly, M.T.; Andersen, R.J. Loloatins A-D, cyclic decapeptide antibiotics produced in culture by a tropical marine bacterium. J. Nat. Prod. 1999, 62, 80-85. [CrossRef]

112. Rahman, H.; Austin, B.; Mitchell, W.J.; Morris, P.C.; Jamieson, D.J.; Adams, D.R.; Spragg, A.M.; Schweizer, M. Novel anti-infective compounds from marine bacteria. Mar. Drugs 2010, 8, 498-518. [CrossRef]

113. Mondol, M.A.M.; Shin, H.J.; Islam, M.T. Diversity of secondary metabolites from marine Bacillus species: Chemistry and biological activity. Mar. Drugs 2013, 11, 2846-2872. [CrossRef] [PubMed]

114. Zhang, H.L.; Hua, H.M.; Pei, Y.H.; Yao, X.S. Three New Cytotoxic Cyclic Acylpeptides from Marine Bacillus sp. Chem. Pharm. Bull. 2004, 52, 1029-1030. [CrossRef] [PubMed]

115. Oku, N.; Adachi, K.; Matsuda, S.; Kasai, H.; Takatsuki, A.; Shizuri, Y. Ariakemicins A and B, novel polyketide-peptide antibiotics from a marine gliding bacterium of the genus Rapidithrix. Org. Lett. 2008, 10, 2481-2484. [CrossRef] [PubMed]

116. Hu, Y.; MacMillan, J.B. Erythrazoles A-B, cytotoxic benzothiazoles from a marine-derived Erythrobacter sp. Org. Lett. 2011, 13, 6580-6583. [CrossRef] [PubMed]

117. Hu, Y.; Legako, A.G.; Espindola, A.P.D.M.; MacMillan, J.B. Erythrolic acids A-E, meroterpenoids from a marine-derived Erythrobacter sp. J. Org. Chem. 2012, 77, 3401-3407. [CrossRef] [PubMed]

118. Di Lorenzo, F.; Palmigiano, A.; Paciello, I.; Pallach, M.; Garozzo, D.; Bernardini, M.-L.L.; Cono, V.L.; Yakimov, M.M.; Molinaro, A.; Silipo, A.; et al. The deep-sea polyextremophile Halobacteroides lacunaris TB21 rough-type LPS: Structure and inhibitory activity towards toxic LPS. Mar. Drugs 2017, 15, 201. [CrossRef]

119. Homann, V.V.; Sandy, M.; Tincu, J.A.; Templeton, A.S.; Tebo, B.M.; Butler, A. Loihichelins A-F, a suite of amphiphilic siderophores produced by the marine bacterium Halomonas LOB-5. J. Nat. Prod. 2009, 72, 884-888. [CrossRef]

120. Wang, L.; Große, T.; Stevens, H.; Brinkhoff, T.; Simon, M.; Liang, L.; Bitzer, J.; Bach, G.; Zeeck, A.; Tokuda, H.; et al. Bioactive hydroxyphenylpyrrole-dicarboxylic acids from a new marine Halomonas sp.: Production and structure elucidation. Appl. Microbiol. Biotechnol. 2006, 72, 816-822. [CrossRef]

121. Bitzer, J.; Große, T.; Wang, L.; Lang, S.; Beil, W.; Zeeck, A. New aminophenoxazinones from a marine Halomonas sp.: Fermentation, structure elucidation, and biological activity. J. Antibiot. 2006, 59, 86-92. [CrossRef]

122. Silipo, A.; Lanzetta, R.; Parrilli, M.; Sturiale, L.; Garozzo, D.; Nazarenko, E.L.; Gorshkova, R.P.; Ivanova, E.P.; Molinaro, A. The complete structure of the core carbohydrate backbone from the LPS of marine halophilic bacterium Pseudoalteromonas carrageenovora type strain IAM 12662T. Carbohydr. Res. 2005, 340, 1475-1482. [CrossRef]

123. Mitova, M.; Tutino, M.L.; Infusini, G.; Marino, G.; De Rosa, S. Exocellular peptides from antarctic psychrophile Pseudoalteromonas haloplanktis. Mar. Biotechnol. 2005, 7, 523-531. [CrossRef] [PubMed] 
124. Shiozawa, H.; Shimada, A.; Takahashi, S. Thiomarinols D, E, F and G, new hybrid antimicrobial antibiotics produced by a marine bacterium. Isolated, structure, and antimicrobial activity. J. Antibiot. 1997, 50, 449-452. [CrossRef] [PubMed]

125. Shiozawa, H.; Kagasaki, T.; Takahashi, S.; Kinoshita, T.; Haruyama, H.; Domon, H.; Utsuib, Y.; Kodama, K. Thiomarinol, a new hybrid antimicrobial antibiotic produced by a marine bacterium fermentation, isolation, structure, and antimicrobial activity. J. Antibiot. 1993, 46, 1834-1842. [CrossRef] [PubMed]

126. Mitchell, S.S.; Nicholson, B.; Teisan, S.; Lam, K.S.; Potts, B.C.M. Aureoverticillactam, a novel 22-atom macrocyclic lactam from the marine actinomycete Streptomyces aureoverticillatus. J. Nat. Prod. 2004, 67, 1400-1402. [CrossRef]

127. Pesic, A.; Baumann, H.I.; Kleinschmidt, K.; Ensle, P.; Wiese, J.; Süssmuth, R.D.; Imhoff, J.F. Champacyclin, a new cyclic octapeptide from Streptomyces strain C42 isolated from the Baltic Sea. Mar. Drugs 2013, 11, 4834-4857. [CrossRef]

128. Kasanah, N.; Triyanto, T. Bioactivities of Halometabolites from Marine Actinobacteria. Biomolecules 2019, 9, 225. [CrossRef]

129. Martin, G.D.A.; Tan, L.T.; Jensen, P.R.; Dimayuga, R.E.; Fairchild, C.R.; Raventos-Suarez, C.; Fenical, W. Marmycins A and B, cytotoxic pentacyclic C-glycosides from a marine sediment-derived actinomycete related to the genus Streptomyces. J. Nat. Prod. 2007, 70, 1406-1409. [CrossRef]

130. Zhou, X.; Huang, H.; Li, J.; Song, Y.; Jiang, R.; Liu, J.; Zhang, S.; Hua, Y.; Ju, J. New anti-infective cycloheptadepsipeptide congeners and absolute stereochemistry from the deep sea-derived Streptomyces drozdowiczii SCSIO 10141. Tetrahedron 2014, 70, 7795-7801. [CrossRef]

131. Bruntner, C.; Binder, T.; Pathom-Aree, W.; Goodfellow, M.; Bull, A.T.; Potterat, O.; Puder, C.; Hörer, S.; Schmid, A.; Bolek, W.; et al. Frigocyclinone, a novel angucyclinone antibiotic produced by a Streptomyces griseus strain from Antarctica. J. Antibiot. 2005, 58, 346-349. [CrossRef]

132. El-Gendy, M.M.A.; Shaaban, M.; Shaaban, K.A.; El-Bondkly, A.M.; Laatsch, H. Essramycin: A first triazolopyrimidine antibiotic isolated from nature. J. Antibiot. 2008, 61, 149-157. [CrossRef]

133. Song, Y.; Huang, H.; Chen, Y.; Ding, J.; Zhang, Y.; Sun, A.; Zhang, W.; Ju, J. Cytotoxic and antibacterial marfuraquinocins from the deep south china sea-derived Streptomyces niveus scsio 3406. J. Nat. Prod. 2013, 76, 2263-2268. [CrossRef] [PubMed]

134. Song, Y.; Li, Q.; Liu, X.; Chen, Y.; Zhang, Y.; Sun, A.; Zhang, W.; Zhang, J.; Ju, J. Cyclic hexapeptides from the deep South China sea-derived Streptomyces scopuliridis SCSIO ZJ46 active against pathogenic gram-positive bacteria. J. Nat. Prod. 2014, 77, 1937-1941. [CrossRef] [PubMed]

135. Takahashi, A.; Kurasawa, S.; Ikeda, D.; Okami, Y.; Takeuchi, T. Altemicidin, a new acaricidal and antitumor substance. I. Taxonomy, fermentation, isolation and physico-chemical and biological properties. J. Antibiot. 1989, 42, 1556-1561. [CrossRef] [PubMed]

136. Pan, H.Q.; Zhang, S.Y.; Wang, N.; Li, Z.L.; Hua, H.M.; Hu, J.C.; Wang, S.J. New spirotetronate antibiotics, lobophorins H and I, from a South China Sea-derived Streptomyces sp. 12A35. Mar. Drugs 2013, 11, 3891-3901. [CrossRef]

137. Moon, K.; Ahn, C.H.; Shin, Y.; Won, T.H.; Ko, K.; Lee, S.K.; Oh, K.B.; Shin, J.; Nam, S.I.; Oh, D.C. New Benzoxazine Secondary Metabolites from an Arctic Actinomycete. Mar. Drugs 2014, 12, 2526-5238. [CrossRef]

138. Schultz, A.W.; Oh, D.C.; Carney, J.R.; Williamson, R.T.; Udwary, D.W.; Jensen, P.R.; Gould, S.J.; Fenical, W.; Moore, B.S. Biosynthesis and structures of cyclomarins and cyclomarazines, prenylated cyclic peptides of marine actinobacterial origin. J. Am. Chem. Soc. 2008, 130, 4507-4516. [CrossRef]

139. Renner, M.K.; Shen, Y.C.; Cheng, X.C.; Jensen, P.R.; Frankmoelle, W.; Kauffman, C.A.; Fenical, W.; Lobkovsky, E.; Clardy, J. Cyclomarins A-C, new antiinflammatory cyclic peptides produced by a marine bacterium (Streptomyces sp.). J. Am. Chem. Soc. 1999, 121, 11273-11276. [CrossRef]

140. Hughes, C.C.; Prieto-Davo, A.; Jensen, P.R.; Fenical, W. The marinopyrroles, antibiotics of an unprecedented structure class from a marine Streptomyces sp. Org. Lett. 2008, 10, 629-631. [CrossRef]

141. Hughes, C.C.; Kauffman, C.A.; Jensen, P.R.; Fenical, W. Structures, Reactivities, and Antibiotic Properties of the Marinopyrroles A-F. J. Org. Chem. 2010, 75, 3240-3250. [CrossRef]

142. Asolkar, R.N.; Jensen, P.R.; Kauffman, C.A.; Fenical, W. Daryamides A-C, weakly cytotoxic polyketides from a marine-derived actinomycete of the genus Streptomyces strain CNQ-085. J. Nat. Prod. 2006, 69, 1756-1759. [CrossRef] 
143. Hughes, C.C.; MacMillan, J.B.; Gaudêncio, S.P.; Jensen, P.R.; Fenical, W. The ammosamides: Structures of cell cycle modulators from a marine-derived Streptomyces species. Angew. Chemi. Int. Ed. 2009, 48, 725-727. [CrossRef]

144. Hughes, C.C.; Fenical, W. Total synthesis of the ammosamides. J. Am. Chem. Soc. 2010, 132, $2528-2529$. [CrossRef] [PubMed]

145. Pan, E.; Jamison, M.; Yousufuddin, M.; MacMillan, J.B. Ammosamide D, an oxidatively ring opened ammosamide analog from a marine-derived Streptomyces variabilis. Org. Lett. 2012, 14, 2390-2393. [CrossRef] [PubMed]

146. Li, F.; Maskey, R.P.; Qin, S.; Sattler, I.; Fiebig, H.H.; Maier, A.; Zeeck, A.; Laatsch, H. Chinikomycins A and B: Isolation, structure elucidation, and biological activity of novel antibiotics from a marine Streptomyces sp. isolate M045. J. Nat. Prod. 2005, 68, 349-353. [CrossRef] [PubMed]

147. Pérez, M.; Crespo, C.; Schleissner, C.; Rodríguez, P.; Zúñiga, P.; Reyes, F. Tartrolon D, a cytotoxic macrodiolide from the marine-derived actinomycete Streptomyces sp. MDG-04-17-069. J. Nat. Prod. 2009, 72, 2192-2194. [CrossRef] [PubMed]

148. Hawas, U.W.; Shaaban, M.; Shaaban, K.A.; Speitling, M.; Maier, A.; Kelter, G.; Fiebig, H.H.; Meiners, M.; Helmke, E.; Laatsch, H. Mansouramycins A-D, cytotoxic isoquinolinequinones from a marine Streptomycete. J. Nat. Prod. 2009, 72, 2120-2124. [CrossRef] [PubMed]

149. Nachtigall, J.; Schneider, K.; Bruntner, C.; Bull, A.T.; Goodfellow, M.; Zinecker, H.; Imhoff, J.F.; Nicholson, G.; Irran, E.; Süssmuth, R.D.; et al. Benzoxacystol, a benzoxazine-type enzyme inhibitor from the deep-sea strain Streptomyces sp. NTK 935. J. Antibiot. 2011, 64, 453-457. [CrossRef]

150. Zhang, W.; Liu, Z.; Li, S.; Yang, T.; Zhang, Q.; Ma, L.; Tian, X.; Zhang, H.; Huang, C.; Zhang, S.; et al. Spiroindimicins A-D: New bisindole alkaloids from a deep-sea-derived actinomycete. Org. Lett. 2012, 14, 3364-3367. [CrossRef]

151. Song, Y.; Liu, G.; Li, J.; Huang, H.; Zhang, X.; Zhang, H.; Ju, J. Cytotoxic and antibacterial angucyclineand prodigiosin-analogues from the deep-sea derived Streptomyces sp. SCSIO 11594. Mar. Drugs 2015, 13, 1304-1316. [CrossRef]

152. You, Z.Y.; Wang, Y.H.; Zhang, Z.G.; Xu, M.J.; Xie, S.J.; Han, T.S.; Feng, L.; Li, X.G.; Xu, J. Identification of two novel anti-fibrotic benzopyran compounds produced by engineered strains derived from Streptomyces xiamenensis M1-94P that originated from deep-sea sediments. Mar. Drugs 2013, 11, 4035-4049. [CrossRef]

153. Miller, E.D.; Kauffman, C.A.; Jensen, P.R.; Fenical, W. Piperazimycins: Cytotoxic hexadepsipeptides from a marine-derived bacterium of the genus Streptomyces. J. Org. Chem. 2007, 72, 323-330. [CrossRef] [PubMed]

154. Sun, M.-L.; Liu, S.-B.; Qiao, L.-P.; Chen, X.-L.; Pang, X.; Shi, M.; Zhang, X.-Y.; Qin, Q.-L.; Zhou, B.-C.; Zhang, Y.-Z.; et al. A novel exopolysaccharide from deep-sea bacterium Zunongwangia profunda SM-A87: Low-cost fermentation, moisture retention, and antioxidant activities. Appl. Microbiol. Biotechnol. 2014, 98, 7437-7445. [CrossRef] [PubMed]

155. Chater, K.F. Recent advances in understanding Streptomyces. F1000Research 2016, 5, 1-16. [CrossRef] [PubMed]

156. Hettiarachchi, S.A.; Lee, S.-J.; Lee, Y.; Kwon, Y.-K.; De Zoysa, M.; Moon, S.; Jo, E.; Kim, T.; Kang, D.-H.; Heo, S.-J.; et al. A rapid and efficient screening method for antibacterial compound-producing bacteria. J. Microbiol. Biotechnol. 2017, 27, 1441-1448. [PubMed]

157. Andreo-Vidal, A.; Sanchez-Amat, A.; Campillo-Brocal, J. The Pseudoalteromonas luteoviolacea L-amino Acid Oxidase with Antimicrobial Activity Is a Flavoenzyme. Mar. Drugs 2018, 16, 499. [CrossRef] [PubMed]

158. Kalitnik, A.A.; Byankina Barabanova, A.O.; Nagorskaya, V.P.; Reunov, A.V.; Glazunov, V.P.; Solov'eva, T.F.; Yermak, I.M. Low molecular weight derivatives of different carrageenan types and their antiviral activity. J. Appl. Phycol. 2013, 25, 65-72. [CrossRef]

159. Queiroz, E.A.I.F.; Fortes, Z.B.; da Cunha, M.A.A.; Sarilmiser, H.K.; Barbosa Dekker, A.M.; Öner, E.T.; Dekker, R.F.H.; Khaper, N. Levan promotes antiproliferative and pro-apoptotic effects in MCF-7 breast cancer cells mediated by oxidative stress. Int. J. Biol. Macromol. 2017, 102, 565-570. [CrossRef]

160. Ruiz-Ruiz, C.; Srivastava, G.K.; Carranza, D.; Mata, J.A.; Llamas, I.; Santamaría, M.; Quesada, E.; Molina, I.J. An exopolysaccharide produced by the novel halophilic bacterium Halomonas stenophila strain B100 selectively induces apoptosis in human T leukaemia cells. Appl. Microbiol. Biotechnol. 2011, 89, 345-355. [CrossRef]

161. Lorenz, P.; Eck, J. Metagenomics and industrial applications. Nat. Rev. Microbiol. 2005, 3, 510-516. [CrossRef] 
162. Prasad, S.; Roy, I. Converting Enzymes into Tools of Industrial Importance. Recent Pat. Biotechnol. 2018, 12, 33-56. [CrossRef]

163. Bommarius, A.S.; Paye, M.F. Stabilizing biocatalysts. Chem. Soc. Rev. 2013, 42, 6534-6565. [CrossRef] [PubMed]

164. Madhavan, A.; Sindhu, R.; Binod, P.; Sukumaran, R.K.; Pandey, A. Strategies for design of improved biocatalysts for industrial applications. Bioresour. Technol. 2017, 245, 1304-1313. [CrossRef] [PubMed]

165. Martínez-Martínez, M.; Bargiela, R.; Ferrer, M. Metagenomics and the Search for Industrial Enzymes. In Biotechnology of Microbial Enzymes: Production, Biocatalysis and Industrial Applications; Brahmachari, G., Demain, A.L., Adrio, J.L., Eds.; Academic Press: Cambridge, MA, USA, 2016; pp. 1-608.

166. Chapman, J.; Ismail, A.; Dinu, C. Industrial Applications of Enzymes: Recent Advances, Techniques, and Outlooks. Catalysts 2018, 8, 238. [CrossRef]

167. Dumorné, K.; Córdova, D.C.; Astorga-Eló, M.; Renganathan, P. Extremozymes: A potential source for industrial applications. J. Microbiol. Biotechnol. 2017, 27, 649-659. [CrossRef] [PubMed]

168. Dalmaso, G.; Ferreira, D.; Vermelho, A. Marine Extremophiles: A Source of Hydrolases for Biotechnological Applications. Mar. Drugs 2015, 13, 1925-1965. [CrossRef] [PubMed]

169. Sarmiento, F.; Peralta, R.; Blamey, J.M. Cold and Hot Extremozymes: Industrial Relevance and Current Trends. Front. Bioeng. Biotechnol. 2015, 3, 1-15. [CrossRef]

170. Di Donato, P.; Buono, A.; Poli, A.; Finore, I.; Abbamondi, G.R.; Nicolaus, B.; Lama, L. Exploring marine environments for the identification of extremophiles and their enzymes for sustainable and green bioprocesses. Sustainability 2019, 11, 149. [CrossRef]

171. Bruno, S.; Coppola, D.; di Prisco, G.; Giordano, D.; Verde, C. Enzymes from Marine Polar Regions and Their Biotechnological Applications. Mar. Drugs 2019, 17, 544. [CrossRef]

172. Yamanaka, Y.; Kazuoka, T.; Yoshida, M.; Yamanaka, K.; Oikawa, T.; Soda, K. Thermostable aldehyde dehydrogenase from psychrophile, Cytophaga sp. KUC-1: Enzymological characteristics and functional properties. Biochem. Biophys. Res. Commun. 2002, 298, 632-637. [CrossRef]

173. Anburajan, L.; Meena, B.; Narendar Sivvaswamy, S. First report on molecular characterization of novel betaine aldehyde dehydrogenase from the halotolerant eubacteria, Bacillus halodurans. Gene Reports 2017, 9 , 131-135. [CrossRef]

174. Kim, H.J.; Joo, W.A.; Cho, C.W.; Kim, C.W. Halophile aldehyde dehydrogenase from Halobacterium salinarum. J. Proteome Res. 2006, 5, 192-195. [CrossRef] [PubMed]

175. Akal, A.L.; Karan, R.; Hohl, A.; Alam, I.; Vogler, M.; Grötzinger, S.W.; Eppinger, J.; Rueping, M. A polyextremophilic alcohol dehydrogenase from the Atlantis II Deep Red Sea brine pool. FEBS Open Bio 2019, 9, 194-205. [CrossRef] [PubMed]

176. Borchert, E.; Knobloch, S.; Dwyer, E.; Flynn, S.; Jackson, S.A.; Jóhannsson, R.; Marteinsson, V.T.; O’Gara, F.; Dobson, A.D.W.W.; O'Gara, F.; et al. Biotechnological Potential of Cold Adapted Pseudoalteromonas spp. Isolated from 'Deep Sea' Sponges. Mar. Drugs 2017, 15, 184. [CrossRef] [PubMed]

177. Izotova, L.S.; Strongin, A.Y.; Chekulaeva, L.N.; Sterkin, V.E.; Ostoslavskaya, V.I.; Lyublinskaya, L.A.; Timokhina, E.A.; Stepanov, V.M. Purification and properties of serine protease from Halobacterium halobium. J. Bacteriol. 1983, 155, 826-830. [CrossRef] [PubMed]

178. Venugopal, M.; Saramma, A.V. An alkaline protease from Bacillus circulans BM15, newly isolated from a mangrove station: Characterization and application in laundry detergent formulations. Indian J. Microbiol. 2007, 47, 298-303. [CrossRef] [PubMed]

179. Wu, S.; Liu, G.; Zhang, D.; Li, C.; Sun, C. Purification and biochemical characterization of an alkaline protease from marine bacteria Pseudoalteromonas sp. 129-1. J. Basic Microbiol. 2015, 55, 1427-1434. [CrossRef]

180. Ibrahim, A.S.S.S.; Al-Salamah, A.A.; El-Badawi, Y.B.; El-Tayeb, M.A.; Antranikian, G. Detergent-, solvent- and salt-compatible thermoactive alkaline serine protease from halotolerant alkaliphilic Bacillus sp. NPST-AK15: Purification and characterization. Extremophiles 2015, 19, 961-971. [CrossRef]

181. Raval, V.H.; Pillai, S.; Rawal, C.M.; Singh, S.P. Biochemical and structural characterization of a detergent-stable serine alkaline protease from seawater haloalkaliphilic bacteria. Process Biochem. 2014, 49, 955-962. [CrossRef]

182. Mothe, T.; Sultanpuram, V.R. Production, purification and characterization of a thermotolerant alkaline serine protease from a novel species Bacillus caseinilyticus. 3 Biotech 2016, 6, 1-10. [CrossRef]

183. Sanchez-Porro, C.; Martin, S.; Mellado, E.; Ventosa, A. Diversity of moderately halophilic bacteria producing extracellular hydrolytic enzymes. J. Appl. Microbiol. 2003, 94, 295-300. [CrossRef] 
184. Sánchez-Porro, C.; Mellado, E.; Pugsley, A.P.; Francetic, O.; Ventosa, A. The haloprotease CPI produced by the moderately halophilic bacterium Pseudoalteromonas ruthenica is secreted by the type II secretion pathway. Appl. Environ. Microbiol. 2009, 75, 4197-4201. [CrossRef] [PubMed]

185. Lama, L.; Romano, I.; Calandrelli, V.; Nicolaus, B.; Gambacorta, A. Purification and characterization of a protease produced by an aerobic haloalkaliphilic species belonging to the Salinivibrio genus. Res. Microbiol. 2005, 156, 478-484. [CrossRef] [PubMed]

186. Behera, B.C.; Sethi, B.K.; Mishra, R.R.; Dutta, S.K.; Thatoi, H.N. Microbial cellulases-Diversity \& biotechnology with reference to mangrove environment: A review. J. Genet. Eng. Biotechnol. 2017, 15, 197-210. [PubMed]

187. Maki, M.; Leung, K.T.; Qin, W. The prospects of cellulase-producing bacteria for the bioconversion of lignocellulosic biomass. Int. J. Biol. Sci. 2009, 5, 500-516. [CrossRef] [PubMed]

188. Dos Santos, Y.Q.; de Veras, B.O.; de França, A.F.J.; Gorlach-Lira, K.; Velasques, J.; Migliolo, L.; Dos Santos, E.A. A new salt-tolerant thermostable cellulase from a marine bacillus sp. Strain. J. Microbiol. Biotechnol. 2018, 28, 1078-1085. [CrossRef]

189. Werner, J.; Ferrer, M.; Michel, G.; Mann, A.J.; Huang, S.; Juarez, S.; Ciordia, S.; Albar, J.P.; Alcaide, M.; La Cono, V.; et al. Halorhabdus tiamatea: Proteogenomics and glycosidase activity measurements identify the first cultivated euryarchaeon from a deep-sea anoxic brine lake as potential polysaccharide degrader. Environ. Microbiol. 2014, 16, 2525-2537. [CrossRef]

190. Zhang, T.; Datta, S.; Eichler, J.; Ivanova, N.; Axen, S.D.; Kerfeld, C.A.; Chen, F.; Kyrpides, N.; Hugenholtz, P.; Cheng, J.F.; et al. Identification of a haloalkaliphilic and thermostable cellulase with improved ionic liquid tolerance. Green Chem. 2011, 13, 2083-2090. [CrossRef]

191. Zhang, C.; Wang, X.; Zhang, W.; Zhao, Y.; Lu, X. Expression and characterization of a glucose-tolerant $\beta-1,4$-glucosidase with wide substrate specificity from Cytophaga hutchinsonii. Appl. Microbiol. Biotechnol. 2017, 101, 1919-1926. [CrossRef]

192. Makhdoumi, A.; Dehghani-Joybari, Z.; Mashreghi, M.; Jamialahmadi, K.; Asoodeh, A. A novel halo-alkali-tolerant and thermo-tolerant chitinase from Pseudoalteromonas sp. DC14 isolated from the Caspian Sea. Int. J. Environ. Sci. Technol. 2015, 12, 3895-3904. [CrossRef]

193. Roman, D.L.; Roman, M.; Sletta, H.; Ostafe, V.; Isvoran, A. Assessment of the properties of chitin deacetylases showing different enzymatic action patterns. J. Mol. Graph. Model. 2019, 88, 41-48. [CrossRef]

194. Zhao, Y.; Park, R.D.; Muzzarelli, R.A.A. Chitin deacetylases: Properties and applications. Mar. Drugs 2010, 8 , 24-46. [CrossRef] [PubMed]

195. Kim, S.B.; Lee, W.; Ryu, Y.W. Cloning and characterization of thermostable esterase from Archaeoglobus fulgidus. J. Microbiol. 2008, 46, 100-107. [CrossRef] [PubMed]

196. Ghati, A.; Paul, G. Purification and characterization of a thermo-halophilic, alkali-stable and extremely benzene tolerant esterase from a thermo-halo tolerant Bacillus cereus strain AGP-03, isolated from 'Bakreshwar' hot spring, India. Process Biochem. 2015, 50, 771-781. [CrossRef]

197. Mohamed, Y.M.; Ghazy, M.A.; Sayed, A.; Ouf, A.; El-Dorry, H.; Siam, R. Isolation and characterization of a heavy metal-resistant, thermophilic esterase from a Red Sea Brine Pool. Sci. Rep. 2013, 3, 3358. [CrossRef]

198. Ferrer, M.; Golyshina, O.V.; Chernikova, T.N.; Khachane, A.N.; Martins, V.A.P.; Santos, D.; Yakimov, M.M.; Timmis, K.N.; Golyshin, P.N. Microbial Enzymes Mined from the Urania Deep-Sea Hypersaline Anoxic Basin. Chem. Biol. 2005, 12, 895-904. [CrossRef] [PubMed]

199. Zhang, S.; Wu, G.; Liu, Z.; Shao, Z.; Liu, Z. Characterization of EstB, a novel cold-active and organic solvent-tolerant esterase from marine microorganism Alcanivorax dieselolei B-5(T). Extremophiles 2014, 18, 251-259. [CrossRef]

200. Rahman, M.A.; Culsum, U.; Tang, W.; Zhang, S.W.; Wu, G.; Liu, Z. Characterization of a novel cold active and salt tolerant esterase from Zunongwangia profunda. Enzyme Microb. Technol. 2016, 85, 1-11. [CrossRef]

201. Garczarek, F.; Dong, M.; Typke, D.; Witkowska, H.E.; Hazen, T.C.; Nogales, E.; Biggin, M.D.; Glaeser, R.M. Octomeric pyruvate-ferredoxin oxidoreductase from Desulfovibrio vulgaris. J. Struct. Biol. 2007, 159, 9-18. [CrossRef]

202. Bock, A.K.; Schönheit, P.; Teixeira, M. The iron-sulfur centers of the pyruvate:ferredoxin oxidoreductase from Methanosarcina barkeri (Fusaro). FEBS Lett. 1997, 414, 209-212. 
203. Chen, C.K.M.; Lee, G.C.; Ko, T.P.; Guo, R.T.; Huang, L.M.; Liu, H.J.; Ho, Y.F.; Shaw, J.F.; Wang, A.H.J. Structure of the Alkalohyperthermophilic Archaeoglobus fulgidus Lipase Contains a Unique C-Terminal Domain Essential for Long-Chain Substrate Binding. J. Mol. Biol. 2009, 390, 672-685. [CrossRef]

204. Akbari, E.; Beheshti-Maal, K.; Nayeri, H. A novel halo-alkalo-tolerant bacterium, Marinobacter alkaliphilus ABN-IAUF-1, isolated from Persian Gulf suitable for alkaline lipase production. Int. J. Environ. Sci. Technol. 2018, 15, 1767-1776. [CrossRef]

205. Jeon, J.H.; Kim, J.-T.; Kim, Y.J.; Kim, H.-K.; Lee, H.S.; Kang, S.G.; Kim, S.-J.; Lee, J.-H. Cloning and characterization of a new cold-active lipase from a deep-sea sediment metagenome. Appl. Microbiol. Biotechnol. 2009, 81, 865-874. [CrossRef] [PubMed]

206. Loperena, L.; Soria, V.; Varela, H.; Lupo, S.; Bergalli, A.; Guigou, M.; Pellegrino, A.; Bernardo, A.; Calviño, A.; Rivas, F.; et al. Extracellular enzymes produced by microorganisms isolated from maritime Antarctica. World J. Microbiol. Biotechnol. 2012, 28, 2249-2256. [CrossRef] [PubMed]

207. Kiran, G.S.; Lipton, A.N.; Kennedy, J.; Dobson, A.D.W.; Selvin, J. A halotolerant thermostable lipase from the marine bacterium Oceanobacillus sp. PUMB02 with an ability to disrupt bacterial biofilms. Bioeng. Bugs 2014, $5,305-318$.

208. Ciok, A.; Dziewit, L. Exploring the genome of Arctic Psychrobacter sp. DAB_AL32B and construction of novel Psychrobacter-specific cloning vectors of an increased carrying capacity. Arch. Microbiol. 2019, 201, 559-569. [CrossRef] [PubMed]

209. Sayed, A.; Ghazy, M.A.; Ferreira, A.J.S.; Setubal, J.C.; Chambergo, F.S.; Ouf, A.; Adel, M.; Dawe, A.S.; Archer, J.A.C.; Bajic, V.B.; et al. A novel mercuric reductase from the unique deep brine environment of Atlantis II in the Red sea. J. Biol. Chem. 2014, 289, 1675-1687. [CrossRef]

210. Zhou, P.; Huo, Y.Y.; Xu, L.; Wu, Y.H.; Meng, F.X.; Wang, C.S.; Xu, X.W. Investigation of mercury tolerance in Chromohalobacter israelensis DSM $6768 \mathrm{~T}$ and Halomonas zincidurans B6T by comparative genomics with Halomonas xinjiangensis TRM 0175T. Mar. Genomics 2014, 19, 15-16. [CrossRef]

211. Sonbol, S.A.; Ferreira, A.J.S.; Siam, R. Red Sea Atlantis II brine pool nitrilase with unique thermostability profile and heavy metal tolerance. BMC Biotechnol. 2016, 16, 1-13. [CrossRef]

212. Hii, S.L.; Tan, J.S.; Ling, T.C.; Ariff, A. Bin Pullulanase: Role in Starch Hydrolysis and Potential Industrial Applications. Enzyme Res. 2012, 2012, 1-14. [CrossRef]

213. Chakdar, H.; Kumar, M.; Pandiyan, K.; Singh, A.; Nanjappan, K.; Kashyap, P.L.; Srivastava, A.K. Bacterial xylanases: Biology to biotechnology. 3 Biotech 2016, 6, 150. [CrossRef]

214. Araki, T.; Tani, S.; Maeda, K.; Hashikawa, S.; Nakagawa, H.; Morishita, T. Purification and Characterization of $\beta-1,3-X y l a n a s e$ from a Marine Bacterium, Vibrio sp. XY-214. Biosci. Biotechnol. Biochem. 1999, 63, 2017-2019. [CrossRef] [PubMed]

215. Wejse, P.L.; Ingvorsen, K.; Mortensen, K.K. Purification and characterisation of two extremely halotolerant xylanases from a novel halophilic bacterium. Extremophiles 2003, 7, 423-431. [CrossRef] [PubMed]

216. Kim, J.J.; Kwon, Y.K.; Kim, J.H.; Heo, S.J.; Lee, Y.; Lee, S.J.; Shim, W.B.; Jung, W.K.; Hyun, J.H.; Kwon, K.K.; et al. Effective microwell plate-based screening method for microbes producing cellulase and xylanase and its application. J. Microbiol. Biotechnol. 2014, 24, 1559-1565. [CrossRef] [PubMed]

217. Møller, M.F.; Kjeldsen, K.U.; Ingvorsen, K. Marinimicrobium haloxylanilyticum sp. nov., a new moderately halophilic, polysaccharide-degrading bacterium isolated from Great Salt Lake, Utah. Antonie van Leeuwenhoek, Int. J. Gen. Mol. Microbiol. 2010, 98, 553-565. [CrossRef]

218. Rattu, G.; Joshi, S.; Satyanarayana, T. Bifunctional recombinant cellulase-xylanase (rBhcell-xyl) from the polyextremophilic bacterium Bacillus halodurans TSLV1 and its utility in valorization of renewable agro-residues. Extremophiles 2016, 20, 831-842. [CrossRef]

219. Kim, J.; Hong, S.-K. Isolation and Characterization of an Agarase-Producing Bacterial Strain, Alteromonas sp. GNUM-1, from the West Sea, Korea. J. Microbiol. Biotechnol. 2012, 22, 1621-1628. [CrossRef]

220. Fu, X.T.; Kim, S.M. Agarase: Review of major sources, categories, purification method, enzyme characteristics and applications. Mar. Drugs 2010, 8, 200-218. [CrossRef]

221. Han, X.; Lin, B.; Ru, G.; Zhang, Z.; Liu, Y.; Hu, Z. Gene Cloning and Characterization of an $\alpha$-Amylase from Alteromonas macleodii B7 for Enteromorpha Polysaccharide Degradation. J. Microbiol. Biotechnol. 2014, 24, 254-263. [CrossRef] 
222. Sewalt, V.J.; Reyes, T.F.; Bui, Q. Safety evaluation of two $\alpha$-amylase enzyme preparations derived from Bacillus licheniformis expressing an $\alpha$-amylase gene from Cytophaga species. Regul. Toxicol. Pharmacol. 2018, 98, 140-150. [CrossRef]

223. Amoozegar, M.A.; Siroosi, M.; Atashgahi, S.; Smidt, H.; Ventosa, A. Systematics of haloarchaea and biotechnological potential of their hydrolytic enzymes. Microbiology 2017, 163, 623-645. [CrossRef]

224. Qin, Y.; Huang, Z.; Liu, Z. A novel cold-active and salt-tolerant $\alpha$-amylase from marine bacterium Zunongwangia profunda: Molecular cloning, heterologous expression and biochemical characterization. Extremophiles 2014, 18, 271-281. [CrossRef] [PubMed]

225. Amoozegar, M.A.; Malekzadeh, F.; Malik, K.A. Production of amylase by newly isolated moderate halophile, Halobacillus sp. strain MA-2. J. Microbiol. Methods 2003, 52, 353-359. [CrossRef]

226. de Lourdes Moreno, M.; Pérez, D.; García, M.; Mellado, E.; De Lourdes Moreno, M.; Pérez, D.; García, M.T.; Mellado, E. Halophilic Bacteria as a Source of Novel Hydrolytic Enzymes. Life 2013, 3, 38-51. [CrossRef] [PubMed]

227. Kiran, K.; Koteswaraiah, P.; Chandra, T.S. Production of Halophilic $\alpha$-Amylase by Immobilized Cells of Moderately Halophilic Bacillus sp. Strain TSCVKK. Br. Microbiol. Res. J. 2012, 2, 146-157. [CrossRef]

228. Uotsu-Tomita, R.; Tonozuka, T.; Sakai, H.; Sakano, Y. Novel glucoamylase-type enzymes from Thermoactinomyces vulgaris and Methanococcus jannaschii whose genes are found in the flanking region of the $\alpha$-amylase genes. Appl. Microbiol. Biotechnol. 2001, 56, 465-473. [CrossRef]

229. Kim, J.W.; Flowers, L.O.; Whiteley, M.; Peeples, T.L. Biochemical confirmation and characterization of the family-57-like $\alpha$-amylase of Methanococcus jannaschii. Folia Microbiol. 2001, 46, 467-473. [CrossRef]

230. Aghajari, N.; Feller, G.; Gerday, C.; Haser, R. Structures of the psychrophilic Alteromonas haloplanctis $\alpha$-amylase give insights into cold adaptation at a molecular level. Structure 1998, 6, 1503-1516. [CrossRef]

231. Mageswari, A.; Subramanian, P.; Chandrasekaran, S.; Sivashanmugam, K.; Babu, S.; Gothandam, K.M. Optimization and immobilization of amylase obtained from halotolerant bacteria isolated from solar salterns. J. Genet. Eng. Biotechnol. 2012, 10, 201-208. [CrossRef]

232. Coronado, M.J.; Vargas, C.; Mellado, E.; Tegos, G.; Drainas, C.; Nieto, J.J.; Ventosa, A. The $\alpha$-amylase gene amyH of the moderate halophile Halomonas meridiana: Cloning and molecular characterization. Microbiology 2000, 146, 861-868. [CrossRef]

233. Singh, G.; Verma, A.K.; Kumar, V. Catalytic properties, functional attributes and industrial applications of $\beta$-glucosidases. 3 Biotech 2016, 6, 1-14. [CrossRef]

234. Sun, J.; Wang, W.; Yao, C.; Dai, F.; Zhu, X.; Liu, J.; Hao, J. Overexpression and characterization of a novel cold-adapted and salt-tolerant GH1 $\beta$-glucosidase from the marine bacterium Alteromonas sp. L82. J. Microbiol. 2018, 56, 656-664. [CrossRef] [PubMed]

235. Hebbale, D.; Bhargavi, R.; Ramachandra, T.V. Saccharification of macroalgal polysaccharides through prioritized cellulase producing bacteria. Heliyon 2019, 5, e01372. [CrossRef]

236. Zhu, B.; Ning, L. Purification and Characterization of a New $k$-Carrageenase from the Marine Bacterium Vibrio sp. NJ-2. J. Microbiol. Biotechnol. 2016, 26, 255-262. [CrossRef] [PubMed]

237. Xiao, A.; Zeng, J.; Li, J.; Zhu, Y.; Xiao, Q.; Ni, H. Molecular cloning, characterization, and heterologous expression of a new k-carrageenase gene from Pseudoalteromonas carrageenovora ASY5. J. Food Biochem. 2018, 42. [CrossRef]

238. Blanco, K.C.; De Lima, C.J.B.; Monti, R.; Martins, J.; Bernardi, N.S.; Contiero, J. Bacillus lehensis-An alkali-tolerant bacterium isolated from cassava starch wastewater: Optimization of parameters for cyclodextrin glycosyltransferase production. Ann. Microbiol. 2012, 62, 329-337. [CrossRef]

239. Suriya, J.; Bharathiraja, S.; Krishnan, M.; Manivasagan, P.; Kim, S.-K. Marine Microbial Amylases. In Advances in food and nutrition research; Elsevier Inc. Academic Press: Cambridge, MA, USA, 2016; Volume 79, pp. 161-177. ISBN 978-0-12-804714-9.

240. Mehta, D.; Satyanarayana, T. Bacterial and archaeal $\alpha$-amylases: Diversity and amelioration of the desirable characteristics for industrial applications. Front. Microbiol. 2016, 7. [CrossRef]

241. Jabbour, D.; Sorger, A.; Sahm, K.; Antranikian, G. A highly thermoactive and salt-tolerant $\alpha$-amylase isolated from a pilot-plant biogas reactor. Appl. Microbiol. Biotechnol. 2013, 97, 2971-2978. [CrossRef]

242. Cowan, D.; Cramp, R.; Pereira, R.; Graham, D.; Almatawah, Q. Biochemistry and biotechnology of mesophilic and thermophilic nitrile metabolizing enzymes. Extremophiles 1998, 2, 207-216. [CrossRef] 
243. Gupta, N.; Balomajumder, C.; Agarwal, V.K. Enzymatic mechanism and biochemistry for cyanide degradation: A review. J. Hazard. Mater. 2010, 176, 1-13. [CrossRef]

244. Nigam, V.K.; Arfi, T.; Kumar, V.; Shukla, P. Bioengineering of Nitrilases Towards Its Use as Green Catalyst: Applications and Perspectives. Indian J. Microbiol. 2017, 57, 131-138. [CrossRef]

245. Kuddus, M. Cold-active enzymes in food biotechnology: An updated mini review. J. Appl. Biol. Biotechnol. 2018, 6, 58-63.

246. Hasan, F.; Shah, A.A.; Hameed, A. Industrial applications of microbial lipases. Enzyme Microb. Technol. 2006, 39, 235-251. [CrossRef]

247. Mahjoubi, M.; Cappello, S.; Souissi, Y.; Jaouani, A.; Cherif, A. Microbial Bioremediation of Petroleum Hydrocarbon-Contaminated Marine Environments. In Recent Insights in Petroleum Science and Engineering; Zoveidavianpoor, M., Ed.; InTechOpen: London, UK, 2018; pp. 325-350.

248. Hassanshahian, M.; Cappello, S. Crude Oil Biodegradation in the Marine Environments. In BiodegradationEngineering and Technology; Rolando Chamy, Ed.; InTechOpen: London, UK, 2013; pp. 101-135.

249. Floodgate, G.D. Biodegradation of hydrocarbons in the sea. In Water Pollution Microbiology; Mitchell, R., Ed.; Wiley-Interscience: New York, NY, USA, 1972; pp. 153-171.

250. Jarvis, I.W.H.; Dreij, K.; Mattsson, Å.; Jernström, B.; Stenius, U. Interactions between polycyclic aromatic hydrocarbons in complex mixtures and implications for cancer risk assessment. Toxicology 2014, 321, 27-39. [CrossRef] [PubMed]

251. Moreno, R.; Jover, L.; Diez, C.; Sardà, F.; Sanpera, C. Ten Years after the Prestige Oil Spill: Seabird Trophic Ecology as Indicator of Long-Term Effects on the Coastal Marine Ecosystem. PLoS ONE 2013, 8. [CrossRef]

252. Sikkema, J.; de Bont, J.A.; Poolman, B. Mechanisms of Membrane Toxicity of Hydrocarbons. Microbiol. Rev. 1995, 59, 201-222. [CrossRef]

253. Catania, V.; Santisi, S.; Signa, G.; Vizzini, S.; Mazzola, A.; Cappello, S.; Yakimov, M.M.; Quatrini, P. Intrinsic bioremediation potential of a chronically polluted marine coastal area. Mar. Pollut. Bull. 2015, 99, 138-149. [CrossRef]

254. Durval, I.J.B.; Resende, A.H.M.; Figueiredo, M.A.; Luna, J.M.; Rufino, R.D.; Sarubbo, L.A. Studies on Biosurfactants Produced using Bacillus cereus Isolated from Seawater with Biotechnological Potential for Marine Oil-Spill Bioremediation. J. Surfactants Deterg. 2018, 22, 349-363. [CrossRef]

255. Hazen, T.C.; Dubinsky, E.A.; DeSantis, T.Z.; Andersen, G.L.; Piceno, Y.M.; Singh, N.; Jansson, J.K.; Probst, A.; Borglin, S.E.; Fortney, J.L.; et al. Deep-sea oil plume enriches indigenous oil-degrading bacteria. Science 2010, 330, 204-208. [CrossRef]

256. Kleindienst, S.; Paul, J.H.; Joye, S.B. Using dispersants after oil spills: Impacts on the composition and activity of microbial communities. Nat. Rev. Microbiol. 2015, 13, 388-396. [CrossRef]

257. Speight, J.G.; El-Gendy, N.S. Introduction to petroleum biotechnology; Elsevier: Amsterdam, The Netherlands, 2017; ISBN 9780128051511.

258. Fuentes, S.; Méndez, V.; Aguila, P.; Seeger, M. Bioremediation of petroleum hydrocarbons: Catabolic genes, microbial communities, and applications. Appl. Microbiol. Biotechnol. 2014, 98, 4781-4794. [CrossRef]

259. Fuentes, S.; Barra, B.; Gregory Caporaso, J.; Seeger, M. From rare to dominant: A fine-tuned soil bacterial bloom during petroleum hydrocarbon bioremediation. Appl. Environ. Microbiol. 2016, 82, 888-896. [CrossRef] [PubMed]

260. Varjani, S.J.; Gnansounou, E. Microbial dynamics in petroleum oilfields and their relationship with physiological properties of petroleum oil reservoirs. Bioresour. Technol. 2017, 245, 1258-1265. [CrossRef] [PubMed]

261. Coulon, F.; McKew, B.A.; Osborn, A.M.; McGenity, T.J.; Timmis, K.N. Effects of temperature and biostimulation on oil-degrading microbial communities in temperate estuarine waters. Environ. Microbiol. 2007, 9, 177-186. [CrossRef] [PubMed]

262. Xu, X.; Liu, W.; Tian, S.; Wang, W.; Qi, Q.; Jiang, P.; Gao, X.; Li, F.; Li, H.; Yu, H. Petroleum HydrocarbonDegrading Bacteria for the Remediation of Oil Pollution Under Aerobic Conditions: A Perspective Analysis. Front. Microbiol. 2018, 9, 1-11. [CrossRef]

263. Fathepure, B.Z. Recent studies in microbial degradation of petroleum hydrocarbons in hypersaline environments. Front. Microbiol. 2014, 5. [CrossRef]

264. Oren, A. Aerobic Hydrocarbon-Degrading Archaea. In Taxonomy, Genomics and Ecophysiology of HydrocarbonDegrading Microbes; Springer International Publishing: Cham, Switzerland, 2017; pp. 1-12. 
265. Gutierrez, T.; Singleton, D.R.; Berry, D.; Yang, T.; Aitken, M.D.; Teske, A. Hydrocarbon-degrading bacteria enriched by the Deepwater Horizon oil spill identified by cultivation and DNA-SIP. ISME J. 2013, 7, 2091-2104. [CrossRef]

266. Yakimov, M.M.; Timmis, K.N.; Golyshin, P.N. Obligate oil-degrading marine bacteria. Curr. Opin. Biotechnol. 2007, 18, 257-266. [CrossRef]

267. McGenity, T.J.; Folwell, B.D.; McKew, B.A.; Sanni, G.O. Marine crude-oil biodegradation: A central role for interspecies interactions. Aquat. Biosyst. 2012, 8, 10. [CrossRef]

268. Head, I.M.; Jones, D.M.; Röling, W.F.M. Marine microorganisms make a meal of oil. Nat. Rev. Microbiol. 2006, 4, 173-182. [CrossRef]

269. Barbato, M.; Mapelli, F.; Magagnini, M.; Chouaia, B.; Armeni, M.; Marasco, R.; Crotti, E.; Daffonchio, D.; Borin, S. Hydrocarbon pollutants shape bacterial community assembly of harbor sediments. Mar. Pollut. Bull. 2016, 104, 211-220. [CrossRef]

270. Barbato, M.; Mapelli, F.; Chouaia, B.; Crotti, E.; Daffonchio, D.; Borin, S. Draft genome sequence of the hydrocarbon-degrading bacterium Alcanivorax dieselolei KS-293 isolated from surface seawater in the Eastern Mediterranean Sea. Genome Announc. 2015, 3. [CrossRef] [PubMed]

271. Wang, W.; Shao, Z. The long-chain alkane metabolism network of Alcanivorax dieselolei. Nat. Commun. 2014, 5. [CrossRef] [PubMed]

272. Li, A.; Shao, Z. Biochemical characterization of a haloalkane dehalogenase DadB from Alcanivorax dieselolei B-5. PLoS ONE 2014, 9. [CrossRef] [PubMed]

273. Scoma, A.; Barbato, M.; Hernandez-Sanabria, E.; Mapelli, F.; Daffonchio, D.; Borin, S.; Boon, N. Microbial oil-degradation under mild hydrostatic pressure (10 MPa): Which pathways are impacted in piezosensitive hydrocarbonoclastic bacteria? Sci. Rep. 2016, 6, 1-14. [CrossRef]

274. Barbato, M.; Scoma, A.; Mapelli, F.; De Smet, R.; Banat, I.M.; Daffonchio, D.; Boon, N.; Borin, S. Hydrocarbonoclastic alcanivorax isolates exhibit different physiological and expression responses to N-dodecane. Front. Microbiol. 2016, 7, 1-14. [CrossRef]

275. Sass, A.M.; McKew, B.A.; Sass, H.; Fichtel, J.; Timmis, K.N.; McGenity, T.J. Diversity of Bacillus-like organisms isolated from deep-sea hypersaline anoxic sediments. Saline Systems 2008, 4, 1-11. [CrossRef]

276. Antunes, A.; Eder, W.; Fareleira, P.; Santos, H.; Huber, R. Salinisphaera shabanensis gen. nov., sp. nov., a novel, moderately halophilic bacterium from the brine-seawater interface of the Shaban Deep, Red Sea. Extremophiles 2003, 7, 29-34. [CrossRef]

277. Palau, M.; Boujida, N.; Manresa, À.; Miñana-Galbis, D. Complete genome sequence of Marinobacter flavimaris LMG 23834T, which is potentially useful in bioremediation. Genome Announc. 2018, 6, 1-2. [CrossRef]

278. Marquez, M.C. Marinobacter hydrocarbonoclasticus Gauthier et al. 1992 and Marinobacter aquaeolei Nguyen et al. 1999 are heterotypic synonyms. Int. J. Syst. Evol. Microbiol. 2005, 55, 1349-1351. [CrossRef]

279. Handley, K.M.; Lloyd, J.R. Biogeochemical implications of the ubiquitous colonization of marine habitats and redox gradients by Marinobacter species. Front. Microbiol. 2013, 4, 1-10. [CrossRef]

280. Gomes, M.B.; Gonzales-Limache, E.E.; Sousa, S.T.P.; Dellagnezze, B.M.; Sartoratto, A.; Silva, L.C.F.; Gieg, L.L.M.; Valoni, E.; Souza, R.S.; Torres, A.P.R.; et al. Exploring the potential of halophilic bacteria from oil terminal environments for biosurfactant production and hydrocarbon degradation under high-salinity conditions. Int. Biodeterior. Biodegradation 2018, 126, 231-242. [CrossRef]

281. Kodama, Y.; Stiknowati, L.I.; Ueki, A.; Ueki, K.; Watanabe, K. Thalassospira tepidiphila sp. nov., a polycyclic aromatic hydrocarbon-degrading bacterium isolated from seawater. Int. J. Syst. Evol. Microbiol. 2008, 58, 711-715. [CrossRef] [PubMed]

282. Budiyanto, F.; Thukair, A.; Al-Momani, M.; Musa, M.M.; Nzila, A. Characterization of Halophilic Bacteria Capable of Efficiently Biodegrading the High-Molecular-Weight Polycyclic Aromatic Hydrocarbon Pyrene. Environ. Eng. Sci. 2018, 35, 616-626. [CrossRef]

283. Castillo-Carvajal, L.C.; Sanz-Martín, J.L.; Barragán-Huerta, B.E. Biodegradation of organic pollutants in saline wastewater by halophilic microorganisms: A review. Environ. Sci. Pollut. Res. 2014, 21, 9578-9588. [CrossRef] [PubMed]

284. Paniagua-Michel, J.; Babu, Z. Fathepure Microbial Consortia and Biodegradation of Petroleum Hydrocarbons in Marine Environments. In Microbial Action on Hydrocarbons; Kumar, V., Kumar, M., Prasad, R., Eds.; Springer Nature: Singapore, 2019; pp. 1-20. 
285. Erdoğmuş, S.F.; Mutlu, B.; Korcan, S.E.; Güven, K.; Konuk, M. Aromatic hydrocarbon degradation by halophilic archaea isolated from ÇamaltI Saltern, Turkey. Water. Air. Soil Pollut. 2013, 224. [CrossRef]

286. Al-Mailem, D.M.; Eliyas, M.; Radwan, S.S. Oil-bioremediation potential of two hydrocarbonoclastic, diazotrophic Marinobacter strains from hypersaline areas along the Arabian Gulf coasts. Extremophiles 2013, 17, 463-470. [CrossRef] [PubMed]

287. Edbeib, M.F.; Wahab, R.A.; Huyop, F. Halophiles: Biology, adaptation, and their role in decontamination of hypersaline environments. World J. Microbiol. Biotechnol. 2016, 32, 1-23. [CrossRef]

(C) 2020 by the authors. Licensee MDPI, Basel, Switzerland. This article is an open access article distributed under the terms and conditions of the Creative Commons Attribution (CC BY) license (http://creativecommons.org/licenses/by/4.0/). 